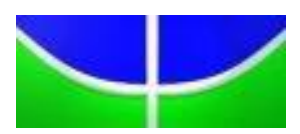

UNIVERSIDADE DE BRASÍLIA

FACULDADE DE CIÊNCIAS DA SAÚDE

PROGRAMA DE PÓS-GRADUAÇÃO EM SAÚDE COLETIVA

CURSO DE MESTRADO ACADÊMICO EM SAÚDE COLETIVA

\title{
A HANSENÍASE NA EXPERIÊNCIA DE VIDA DE PESSOAS ATENDIDAS EM AMBULATÓRIO DE REFERÊNCIA NO \\ DISTRITO FEDERAL
}

Cristina Hamester

Orientador: Prof. Dr. Miguel Ângelo Montagner

Brasília, 2016 


\section{A HANSENÍASE NA EXPERIÊNCIA DE VIDA DE PESSOAS ATENDIDAS EM AMBULATÓRIO DE REFERÊNCIA NO DISTRITO FEDERAL}

CRISTINA HAMESTER

Dissertação de Mestrado apresentada ao programa de Pós-Graduação em Saúde Coletiva da Universidade de Brasília, para a obtenção do título de mestre em Saúde Coletiva.

Orientador:

Prof ${ }^{\circ}$. Dr. Miguel Ângelo Montagner 
Aos meus avós (in memorian)

Norma e Edwino

Olga e Alberto 


\section{AGRADECIMENTOS}

Aos meus pais Selia e Otavio pela dedicação que sempre tiveram e pelo esforço que nunca mediram para garantir o estudo dos filhos.

Aos meus irmãos Ângela e Moisés pela amizade e carinho.

A minha sobrinha Cecília que me alegra e inspira com seu lindo sorriso.

A todos meus amigos que de longe ou de perto me incentivaram a seguir nesta jornada.

Aos professores do programa de pós-graduação em Saúde Coletiva, em especial ao meu orientador Prof. Dr. Miguel Ângelo Montagner.

A equipe do departamento de Dermatologia do HUB.

A todos entrevistados que compartilharam um pouco de suas vidas comigo.

Aos meus felinos pela companhia diária. 
"Cada pessoa deve trabalhar para o seu aperfeiçoamento e, ao mesmo tempo, participar da responsabilidade coletiva por toda a humanidade."

Marie Curie 


\section{LISTA DE TABELAS}

Tabela 1 - Perfil dos entrevistados.

Tabela 2 - Distribuição dos entrevistados segundo Estado de residência.

Tabela 3 - Distribuição dos entrevistados segundo sexo.

Tabela 4 - Distribuição dos s entrevistados segundo renda familiar.

Tabela 5 - Distribuição dos entrevistados segundo quantidade de pessoas morando por residência.

Tabela 6 - Distribuição dos entrevistados segundo escolaridade.

Tabela 7 - Distribuição dos entrevistados segundo raça/cor.

Tabela 8 - Distribuição dos entrevistados segundo faixa etária.

Tabela 9- Distribuição dos entrevistados segundo ocupação profissional.

Tabela 10 - Distribuição dos entrevistados segundo sintomas iniciais.

Tabela 11 - Distribuição dos entrevistados segundo tempo de diagnóstico. 


\section{ABREVIATURAS E SIGLAS UTILIZADAS}

BCG Bacilo de Calmette-Guérin

CAAE Certificado de Apresentação para Apreciação Ética

CEP Comitê de Ética em Pesquisa

CONEP Comissão Nacional de Ética em Pesquisa

CFZ Clofazimina

DDS Dapsona

DF Distrito Federal

DTN Doenças Tropicais Negligenciadas

DSS Determinantes Sociais da Saúde

HUB Hospital Universitário de Brasília

M. leprae Mycobacterium leprae

MB Multibacilar

MDT Multidrogaterapia

$\mathrm{MH} \quad$ Mal de Hansen ou Morbus Hansen

MS Ministério da Saúde

PLOS Public Library of Science

PB Paucibacilar

PBF Programa Bolsa Família

PQT Poliquimioterapia

OMS Organização Mundial da Saúde

RMP Rifampicina

SUS Sistema Único de Saúde

TCLE Termo de Consentimento Livre e Esclarecido

UBS Unidade Básica de Saúde

UnB Universidade de Brasília

WHO World Health Organization 


\section{Sumário}

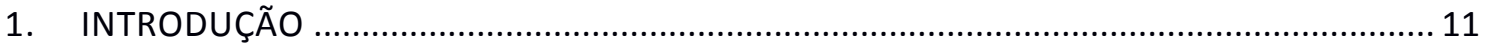

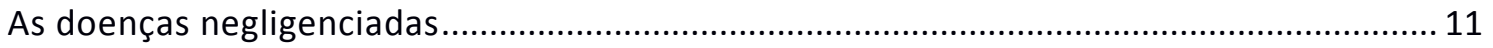

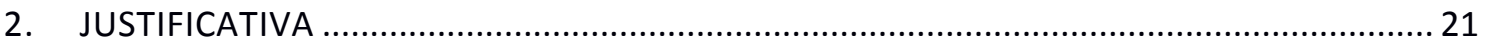

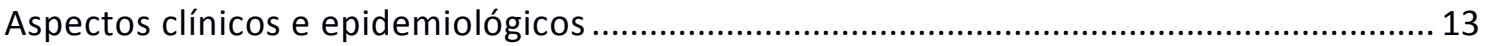

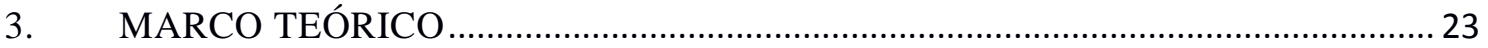

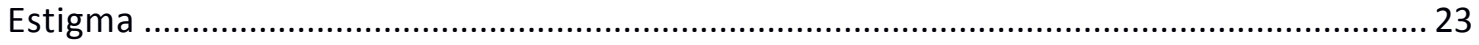

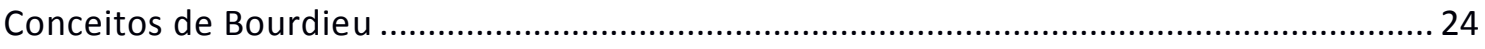

Adaptação dos conceitos de Bourdieu à realidade brasileira ................................................ 26

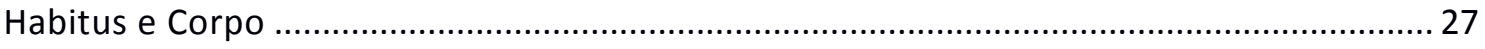

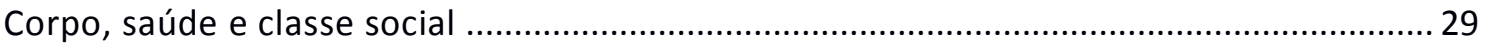

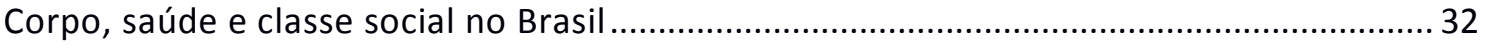

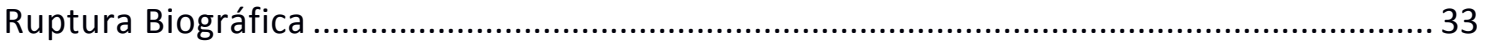

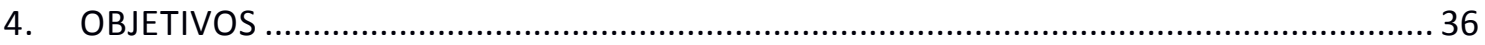

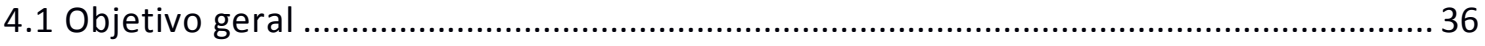

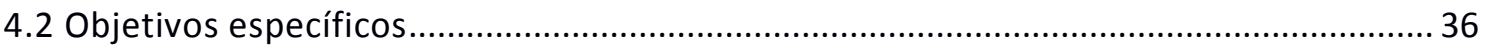

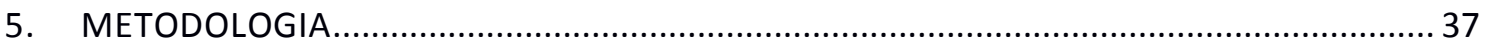

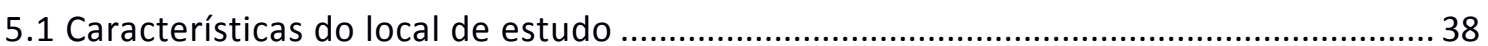

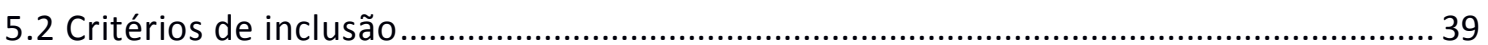

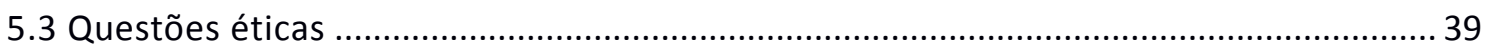

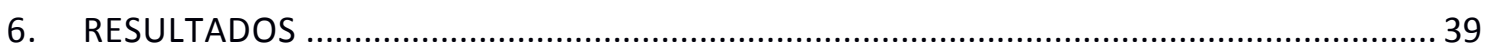

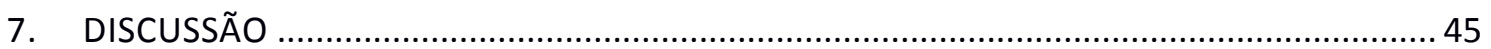

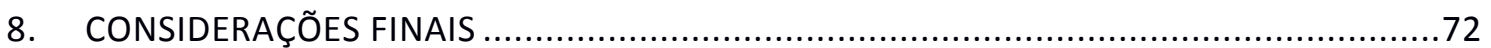

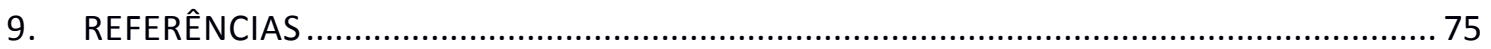

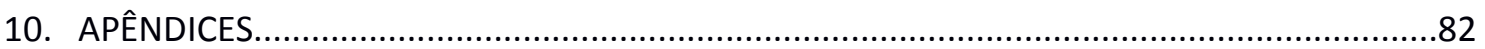




\section{RESUMO}

A hanseníase é uma doença transmitida pelo $M$. leprae e faz parte do grupo das doenças negligenciadas, as quais são endêmicas em populações de baixa renda, possui baixa mortalidade, é estigmatizante e provoca incapacidades e deformidades físicas, principalmente quando não diagnosticada precocemente. O objetivo deste estudo foi analisar a experiência das pessoas diagnosticadas com hanseníase, atendidas no Hospital Universitário de Brasília, e como estas vivenciam a doença e o tratamento em seus corpos e em suas relações sociofamiliares e profissionais. Trata-se de uma pesquisa qualitativa, feita por meio de entrevista semiestruturada, que contemplou dados pessoais, início da doença, medicação, satisfação com o atendimento, preconceito, dificuldades e mudanças após o diagnóstico. Foram entrevistados 27 pacientes que se encontravam em tratamento ou acompanhamento de hanseníase. O perfil das pessoas em tratamento de hanseníase é composto majoritariamente por: sexo feminino; renda familiar de 1 a 2 salários mínimos; ensino fundamental incompleto; pardos; têm profissões sem carteira assinada, de baixo salário; idade entre 30 e 40 anos; a composição familiar é de 3 a 4 pessoas por residência; provenientes de áreas periféricas de Brasília e entorno do Distrito Federal. A hanseníase, apesar de ter cura, continua envolta em preconceitos, estigmas e desconhecimentos acerca de suas características, transmissibilidade e tratamento, principalmente devido à falta de informações e conhecimento. A hanseníase é uma doença promotora e perpetuadora da pobreza, é um sintoma de desvantagem social, intelectual, de desenvolvimento, e, claro, de pobreza. A população acometida compartilha características que lhes permite persistir em condições de pobreza, sugerindo um habitus em comum. O estudo sugere também que, após o diagnóstico de hanseníase, ocorrem diversas mudanças e adaptações à nova realidade destes pacientes, tanto na vida social, familiar e profissional.

Palavras-chave: doença negligenciada, hanseníase, perfil dos entrevistados, pobreza, preconceito. 


\title{
LEPROSY ON THE LIFE EXPERIENCE OF PEOPLE TREATED AT THE FEDERAL DISTRICT REFERENCE AMBULATORY
}

\begin{abstract}
Leprosy is a transmittable disease caused by $M$. leprae and is part of a group of neglected diseases. This disease is endemic in low income populations, possesses a low mortality rate, stigmatizing and can produce handicaps and physical deformities when not diagnosed in early stages. This study's main goal was to analyze the experiences of people diagnosed with leprosy who were treated at Brasilia's University Hospital and how they experienced the disease and their treatments, as well as how it affected their social-familial and professional relationships. It is a qualitative research study, conducted through semi-structured interviews, that analyzed personal information, the disease's beginning, medication, satisfaction with the services provided, prejudices, difficulties and changes after the diagnosis. Twenty-seven people were interviewed who were undergoing treatment or who were under observation for leprosy. The average people's background was discovered to mainly be: female patients; casual workers, with low salary; family income of 1 or 2 minimum wages; incomplete basic education; brown skinned; aged between 30 and 40; family composition of 3 to 4 persons per home; coming from Brasilia's periphery and the Federal District's surrounding area. Although there is a cure, leprosy still evokes prejudices, stigmas and misinformation about its characteristics, transmission and treatment, mainly due to the lack of information and knowledge. Leprosy is a disease that promotes and perpetuates poverty, it's a symptom of social inequality, intellectual, of development, and, of course, of poverty. The population affected share characteristics that cause them to persist in poverty conditions, suggesting a common habitus. The study also suggests that, after the leprosy diagnosis, several changes and adaptations occur to the people's new reality, in their social, familial and professional lives.
\end{abstract}

Keywords: leprosy, neglected disease, people background, prejudice, poverty. 


\section{INTRODUÇÃO}

\section{As doenças negligenciadas}

As doenças negligenciadas são um conjunto de doenças causadas por agentes infecciosos e parasitários que são endêmicas em populações de baixa renda, que vivem, sobretudo, em países em desenvolvimento na África, Ásia e nas Américas (GARCIA, 2011). Por afetarem as populações mais empobrecidas nos países menos desenvolvidos do mundo, essas doenças não constituem um mercado lucrativo para as indústrias farmacêuticas (PONTES, 2009).

A Public Library of Science (PLOS) utiliza o termo doenças tropicais negligenciadas, e as define como um grupo de doenças crônico-infecciosas promotoras de pobreza. Isso porque impactam na saúde e desenvolvimento de crianças e gestantes e afetam o rendimento dos trabalhadores, além de serem doenças estigmatizantes, marginalizantes e de elevada morbidade. As doenças tropicais negligenciadas são um sintoma de pobreza e desvantagem social, intelectual e de desenvolvimento.

Embora clinicamente diversas, as doenças tropicais negligenciadas compartilham características que lhes permitem persistir em condições de pobreza, onde se aglomeram e frequentemente se sobrepõem. Como as mais afetadas são as populações mais pobres e que têm pouca voz política, essas doenças não têm prioridade nas políticas públicas de saúde (HOTEZ, 2006).

A Organização Mundial de Saúde (OMS) e outras agências internacionais de saúde identificaram um grupo de 13 doenças infecciosas como as doenças tropicais negligenciadas (DTN). Estas doenças listadas, que incluem hanseníase, leishmaniose visceral, oncocercose, dracunculíase, esquistossomose, ancilostomose e filariose linfática, atingem as pessoas mais pobres do mundo, vivendo em áreas de difícil acesso e rurais de países de baixa renda na África subsaariana, Ásia e nas Américas. Elas infligem sofrimento ao causar incapacidades, desfigurar, redução da capacidade produtiva e estigma social. Diferentemente das doenças mais conhecidas como imunodeficiência adquirida (HIV), malária e tuberculose, as DTN não recebem atenção internacional suficiente. As doenças negligenciadas são encontradas entre pessoas esquecidas em áreas geográficas isoladas e em áreas extremamente pobres (HOTEZ, 2006b). 
Populações empobrecidas e marginalizadas com DTN representam mercados com a mais baixa prioridade para a indústria farmacêutica dos EUA e da Europa. As DTN não ocorrem no mundo industrializado ou mesmo entre a classe média substancialmente rica dos países em desenvolvimento. Também não são um risco para viajantes estrangeiros e para os militares. Isto contrasta com o substancial mercado comercial para HIV/AIDS, malária e tuberculose, chamadas de "as três grandes" (HOTEZ, 2006b).

Entre os Objetivos de Desenvolvimento do Milênio (ODM), propostos pela Organização das Nações Unidas (ONU) na Declaração do Milênio, em 2000, estão previstas metas de combate ao vírus da imunodeficiência humana (HIV) e à AIDS, à malária e a outras doenças, que devem ser cumpridas até 2015 (IPEA, 2010). As principais metas do Brasil para o sexto ODM são, até 2015, ter detido a propagação do HIV/AIDS e começado a inverter a tendência atual; ter detido a incidência da malária e de outras doenças importantes e começado a inverter a tendência atual; ter reduzido a incidência da malária e da tuberculose e, até 2015, ter eliminado a hanseníase. (GARCIA, 2011).

O Brasil foi um dos poucos países do mundo que não conseguiram atingir a meta de eliminação da hanseníase como problema de saúde pública até 2015, ou seja, uma prevalência de menos de um caso por 10 mil habitantes. Para isto, 255 municípios foram considerados prioritários: 72,55\% (185/255) estão situados nas regiões norte e nordeste, onde residem 76,5\% da população em extrema pobreza (BRASIL, 2015).

A hanseníase, apesar de apresentar baixa mortalidade, é uma doença estigmatizante, responsável por diversas incapacidades e deformidades físicas. A doença acompanha a humanidade há milênios. Entretanto, por afetar os mais pobres entre os pobres, essa e outras doenças negligenciadas não representam mercados comerciais favoráveis para medicamentos e vacinas, e a farmacopeia para seu tratamento tem permanecido essencialmente inalterada desde a metade do século XX (HOTEZ et al, 2006a). E isso é muito preocupante, tendo em vista o impacto das doenças negligenciadas sobre a saúde global. O controle destas pode promover um impacto positivo não apenas àqueles indicadores relacionados diretamente à saúde, mas também sobre diversos indicadores dos ODM (HOTEZ et al, 2006b). 


\section{HANSENÍASE}

\section{Aspectos clínicos e epidemiológicos}

A hanseníase é uma das mais antigas doenças que acometem o homem. As referências mais remotas datam de 600 a.C. e procedem da Ásia, que, juntamente com a África, podem ser consideradas o berço da doença. Outrora motivo de estigma e exclusão, há mais de 20 anos, a doença tem tratamento capaz de curar a totalidade dos casos (BRASIL, 2014.)

A hanseníase é conhecida há muito tempo pela denominação "lepra", terminologia evitada por ser estigmatizante, pejorativa e marginalizante, em especial para os doentes e seus familiares. Numa tentativa de diminuir os estigmas da doença, o nome 'lepra' foi substituído por 'hanseníase' em 1995, com a Lei n 9.010, de 29 de março de 1995. No entanto, desde a publicação da Portaria $n^{\circ}$ 165, de 14/05/1976, do Ministério da Saúde, estava proibido o uso do termo 'lepra' e seus derivados nos documentos oficiais do órgão.

É uma doença infectocontagiosa, crônica, causada pelo Mycobacterium leprae (M. leprae), descoberta e descrita por Gerhard H. A. Hansen, em 1868, em Bergen, na Noruega. A hanseníase compromete o tecido cutâneo, mucoso e o sistema nervoso periférico. A predileção pela pele e nervos periféricos confere-lhe características peculiares, tornando o seu diagnóstico simples na maioria dos casos. Assim, a gravidade da doença não é só avaliada pelo número de doentes existentes, ou pela sua contagiosidade, mas pelas incapacidades, produzidas pelo dano neurológico, pelos problemas psicossociais e pela longa duração do tratamento. Pode gerar incapacidades e deformidades advindas da evolução crônica da doença não tratada e resultando em prejuízos socioeconômicos e na qualidade de vida, determinando estigmas, preconceitos e problemas psicológicos ao longo da vida dos doentes (ARANTES, 2010; ARAÚJO, 2003).

A primeira evidência clínica é a disestesia cutânea - sintoma característico e sempre constante na hanseníase. Inicialmente ocorrem alterações da sensibilidade térmica: hiperestesia (durante período fugaz), seguida de hipoestesia e após vários 
meses, anestesia. A seguir, ocorre perda progressiva da sensibilidade dolorosa e por último, da tátil (VERONESE, 2005).

Os principais sinais e sintomas da doença são: manchas esbranquiçadas (hipocrômicas), acastanhadas ou avermelhadas, com alterações de sensibilidade (a pessoa sente formigamentos, choques e câimbras que evoluem para dormência); pápulas, infiltrações, tubérculos e nódulos, normalmente sem sintomas; diminuição ou queda de pelos, localizada ou difusa, especialmente sobrancelhas; falta ou ausência de sudorese no local. Também podem ser observados: dor e/ou espessamento de nervos periféricos; diminuição e/ou perda de sensibilidade nas áreas dos nervos afetados, principalmente nos olhos, mãos e pés; diminuição e/ou perda de força nos músculos inervados por estes nervos, principalmente nos membros superiores e inferiores e por vezes, pálpebras; edema de mãos e pés; febre e artralgia; entupimento, feridas e ressecamento do nariz; nódulos eritematosos dolorosos; mal-estar geral e ressecamento dos olhos (BRASIL, 2008).

O M. leprae tem a capacidade de infectar grande número de indivíduos (alta infectividade), no entanto, poucos adoecem (baixa patogenicidade), propriedades estas que não são função apenas de suas características intrínsecas, mas que dependem, sobretudo, de sua relação com o hospedeiro e grau de endemicidade do meio, entre outros. O domicílio é apontado como importante espaço de transmissão da doença, embora ainda existam lacunas de conhecimento quanto aos prováveis fatores de risco implicados, especialmente aqueles relacionados ao ambiente social. $\mathrm{O}$ alto potencial incapacitante da hanseníase está diretamente relacionado ao poder imunogênico do M. leprae. (BRASIL, 2014a)

O período médio de incubação é de dois a cinco anos. Há descrição de períodos extremos entre seis e vinte anos, devido à lenta multiplicação dos bacilos e a resistência imune celular. A moléstia é altamente incapacitante, devido ao neurotropismo do $M$. leprae, este fato contribui para a perpetuação do estigma (VERONESE, 2005).

A infecção pelo $M$. leprae envolve a existência de predisposição individual e de contato íntimo e prolongado com algum portador sem tratamento, mostrando-se sensível à presença de vulnerabilidade social. A maioria das pessoas que entra em contato com o bacilo é resistente e não adoece. Mas, quando esse contato ocorre entre indivíduos 
malnutridos e em ambiente insalubre, há maior possibilidade de desenvolver a doença (LOPES E RANGEL, 2014).

No Brasil, há predomínio de doentes multibacilares (contagiantes). Portanto, trata-se de uma moléstia de muita importância, pois ainda é um grande problema de saúde pública. A principal forma de contágio é inter-humana e o maior risco de contágio é a convivência domiciliar com o doente bacilífero. Quanto mais íntimo e prolongado for o contato, maior será a possibilidade de adquirir a infecção (VERONESE, 2005).

As manifestações clínicas da doença estão diretamente relacionadas ao tipo de resposta ao M. leprae:

- Hanseníase indeterminada - forma inicial, evolui espontaneamente para a cura na maioria dos casos ou evolui para as formas polarizadas em cerca de $25 \%$ dos casos, o que pode ocorrer no prazo de 3 a 5 anos. Geralmente, encontra-se apenas uma lesão, de cor mais clara que a pele normal, com distúrbio da sensibilidade, ou áreas circunscritas de pele com aspecto normal e com distúrbio de sensibilidade, podendo ser acompanhadas de alopecia e/ou anidrose.

- Hanseníase tuberculoide - forma mais benigna e localizada que aparece em pessoas com alta resistência ao bacilo. As lesões são poucas (ou uma única), de limites bem definidos e pouco elevados, e com ausência de sensibilidade. Ocorre comprometimento simétrico de troncos nervosos, podendo causar dor, fraqueza e atrofia muscular. Próximos às lesões em placa, podem ser encontrados filetes nervosos espessados. Nas lesões e/ou trajetos de nervos, pode haver perda total da sensibilidade térmica, tátil e dolorosa, ausência de sudorese e/ou alopecia. Pode ocorrer a forma nodular infantil, que acomete crianças de 1 a 4 anos, quando há um foco multibacilar no domicílio. A clínica é caracterizada por lesões papulosas ou nodulares, únicas ou em pequeno número, principalmente na face.

- Hanseníase dimorfa (ou borderline) - forma intermediária, resultante de uma imunidade também intermediária, com características clínicas e laboratoriais que podem se aproximar do polo tuberculoide ou virchowiano. A variedade de lesões cutâneas é maior e estas apresentam-se como placas, nódulos eritemato-acastanhados, em grande número, com tendência à simetria. As lesões mais características dessa forma clínica são denominadas lesões pré-foveolares ou foveolares, sobre-elevadas ou não, com áreas 
centrais deprimidas e aspecto de pele normal, com limites internos nítidos e externos difusos. O acometimento dos nervos é mais extenso, podendo ocorrer neurites agudas de grave prognóstico.

- Hanseníase virchowiana (ou lepromatosa) - nesse caso, a imunidade celular é nula e o bacilo se multiplica com mais facilidade, levando a uma maior gravidade, com anestesia dos pés e mãos. Esse quadro favorece os traumatismos e feridas, que por sua vez podem causar deformidades, atrofia muscular, inchaço das pernas e surgimento de nódulos na pele. As lesões cutâneas caracterizam-se por placas infiltradas e nódulos (hansenomas), de coloração eritemato-acastanhada ou ferruginosa, que podem se instalar também na mucosa oral. Podem ocorrer infiltração facial com madarose superciliar e ciliar, hansenomas nos pavilhões auriculares, espessamento e acentuação dos sulcos cutâneos. Pode, ainda, ocorrer acometimento da laringe, com quadro de rouquidão, e de órgãos internos (fígado, baço, suprarrenais e testículos), bem como a hanseníase histoide, com predominância de hansenomas com aspecto de queloides ou fibromas, com grande número de bacilos. Ocorre comprometimento de maior número de troncos nervosos de forma simétrica (BRASIL, 2014a).

Apenas o grupo indeterminado, que é a fase inicial e matricial de todas as outras manifestações clínicas, adequadamente tratados, não deixa nenhuma sequela. Nos doentes já polarizados e tratados, o menor grau de sequela é anestesia localizada (VERONESE, 2005).

A hanseníase é a principal causa de incapacidade física permanente dentre as doenças infectocontagiosas. A doença e as deformidades a ela associadas são responsáveis pelo estigma social e pela discriminação contra os pacientes e suas famílias em muitas sociedades (OMS, 2006).

Infelizmente, o diagnóstico tem sido feito tardiamente. $\mathrm{O}$ doente, em geral, percorre vários médicos, com queixas específicas da doença (parestesia, neurite, rinite, artralgia, manchas na pele) e nem mesmo se aventa a hipótese de hanseníase. No Brasil, 75\% dos doentes são diagnosticados quando já apresentam algum grau de incapacidade física (VERONESE, 2005).

Mesmo a hanseníase tendo um bacilo causador, sua análise remete à reflexão sobre condições coletivas de vida, ultrapassando a perspectiva dos hábitos e atitudes 
individuais. É um complexo problema de saúde pública, que tem afetado um significativo contingente populacional, ressaltando a importância do debate e intervenções sobre as iniquidades em saúde (LOPES E RANGEL, 2014).

Embora a hanseníase hoje se mantenha nos países mais pobres e nestes nos estratos de população menos favorecidos, não se sabe ao certo o peso de variáveis como moradia, estado nutricional, infecções concomitantes (HIV e malária), e infecções prévias por outras micobactérias (ARAÚJO, 2003).

A hanseníase pode apresentar períodos de alterações imunes, os estados reacionais. Na hanseníase dimorfa, as lesões tornam-se avermelhadas e os nervos, inflamados e doloridos. Na forma virchowiana, surge o eritema nodoso hansênico: lesões nodulares, endurecidas e dolorosas nas pernas, braços e face, acompanhadas de febre, mal-estar, queda do estado geral e inflamação de órgãos internos. Essas reações podem ocorrer mesmo em pessoas que já concluíram o tratamento. Os estados reacionais são a principal causa de lesões dos nervos e de incapacidades provocadas pela hanseníase. Os estados reacionais ou reações hansênicas são alterações do sistema imunológico que se exteriorizam como manifestações inflamatórias agudas e subagudas, mais frequentes nos casos MB. Essas reações podem ocorrer antes do diagnóstico da doença, durante ou depois do tratamento com poliquimioterapia (PQT), e caracterizamse por:

- Reação do Tipo 1 ou reação reversa (RR) - aparecimento de novas lesões dermatológicas (manchas ou placas), infiltração, alterações de cor e edema nas lesões antigas, com ou sem espessamento e neurite;

- Reação do Tipo 2 ou reação de eritema nodoso hansênico (ENH) - é a expressão clínica mais frequente, cujo quadro inclui nódulos subcutâneos dolorosos, acompanhados ou não de febre, dores articulares e mal-estar generalizado, com ou sem espessamento e neurite.

As complicações da hanseníase, muitas vezes, confundem-se com a evolução do próprio quadro clínico da doença. Muitas delas dependem da resposta imune dos indivíduos acometidos, outras estão relacionadas à presença do M. leprae nos tecidos e, por fim, algumas das complicações decorrem das lesões neurais características da hanseníase. 
O diagnóstico é essencialmente clínico e epidemiológico, realizado por meio da análise da história e condições de vida do paciente, além do exame dermatoneurológico para identificar lesões ou áreas de pele com alteração de sensibilidade e/ou comprometimento de nervos periféricos. O diagnóstico de hanseníase deve ser recebido de modo semelhante ao de outras doenças curáveis. Se vier a causar impacto psicológico, tanto em quem adoeceu quanto nos familiares ou em pessoas de sua rede social, essa situação requererá uma abordagem apropriada pela equipe de saúde, que favoreça a aceitação do problema, superação das dificuldades e maior adesão ao tratamento. Essa atenção deve ser oferecida no momento do diagnóstico, bem como no decorrer do tratamento da doença e, se necessário, após a alta. (BRASIL, 2014a)

O Ministério da Saúde define como caso de hanseníase para tratamento, quando um ou mais dos seguintes achados encontram-se presentes: lesão de pele com alteração de sensibilidade, espessamento de tronco nervoso ou baciloscopia positiva na pele (ARAÚJO, 2003).

Visando o tratamento com o esquema PQT/OMS (poliquimioterapia), a classificação operacional do caso de hanseníase é baseada no número de lesões cutâneas, de acordo com os seguintes critérios:

- PB - casos com até 5 lesões de pele;

- MB - casos com mais de 5 lesões de pele (BRASIL, 2008).

O tratamento da hanseníase é eminentemente ambulatorial, utiliza os esquemas terapêuticos padronizados (poliquimioterapia - PQT) e está disponível nas unidades públicas de saúde definidas pelos municípios para o tratamento do doente com hanseníase. A PQT é uma associação de rifampicina, dapsona e clofazimina, na apresentação de blíster que mata o bacilo e evita a evolução da doença, levando à cura. O bacilo morto é incapaz de infectar outras pessoas, rompendo a cadeia epidemiológica da doença. Logo no início do tratamento, a transmissão da doença é interrompida e, se o tratamento é realizado de forma completa e correta, a cura é garantida (BRASIL, 2014a).

Os esquemas terapêuticos são utilizados de acordo com a classificação operacional: para $\mathrm{PB}$, recomenda-se a administração de seis blisters contendo a 
associação de dapsona e clofazimina, sendo uma dose mensal supervisionada, em até nove meses; para $\mathrm{MB}$, recomenda-se a administração de 12 blisters contendo a associação de dapsona, clofazimina e rifampicina, sendo uma dose mensal supervisionada, em até 18 meses. Já no caso de pessoas com intolerância a um dos medicamentos do esquema padrão, são indicados esquemas substitutivos. A alta por cura é dada após a administração do número de doses preconizado pelo esquema terapêutico, dentro do prazo recomendado (BRASIL, 2014a).

Os pacientes devem ser agendados para retorno a cada 28 dias. Nessas consultas, eles tomam a dose supervisionada no serviço de saúde e recebem a cartela com os medicamentos nas doses a serem auto administradas em domicílio. Essa oportunidade deve ser aproveitada para avaliação do doente, esclarecimento de dúvidas e orientações. Além disso, deve-se reforçar a importância do exame dos contatos e agendar o exame clínico e a vacinação dos contatos. O cartão de agendamento deve ser usado para registro da data de retorno à unidade de saúde e para o controle da adesão ao tratamento. Os pacientes que não comparecerem à dose supervisionada deverão ser visitados em seus domicílios, no máximo em 30 dias, com o objetivo de manter o tratamento e evitar o abandono (BRASIL, 2014a).

Técnicas de autocuidados devem fazer parte das orientações de rotina do atendimento mensal, sendo recomendada a organização de grupos de pacientes e familiares ou outras pessoas de sua convivência, que possam apoiá-los na execução dos procedimentos recomendados. A prática das técnicas de autocuidado deve ser avaliada sistematicamente, para evitar piora do dano neural por execução inadequada. Em todas as situações, o esforço realizado pelos doentes deve ser valorizado, para estimular a continuidade das práticas de autocuidado apoiado (BRASIL, 2014a).

O encerramento da PQT deve acontecer segundo os critérios de regularidade no tratamento: número de doses e tempo de tratamento, de acordo com cada esquema mencionado anteriormente, sempre com avaliação neurológica simplificada, avaliação do grau de incapacidade física e orientação para os cuidados após a alta.

A principal forma de prevenir a instalação de deficiências e incapacidades físicas é o diagnóstico precoce. A prevenção de deficiências (temporárias) e incapacidades (permanentes) não deve ser dissociada do tratamento de PQT. As ações de prevenção de 
incapacidades e deficiências fazem parte da rotina dos serviços de saúde e são recomendadas para todos os pacientes. A prevenção das incapacidades físicas é realizada por meio de técnicas simples e orientação ao doente para a prática regular de autocuidado apoiado. São procedimentos, técnicas e exercícios que o próprio indivíduo, devidamente apoiado, incentivado e capacitado, deverá realizar regularmente no próprio domicílio e em outros ambientes, durante o tratamento e após a alta, para prevenir incapacidades e deformidades físicas decorrentes da hanseníase. Os pacientes devem ser orientados a fazer a auto inspeção diária e, se necessário, estimulados a usar proteção, especialmente para os olhos, nariz, mãos e pés (BRASIL, 2008).

No Brasil, em 2014, a prevalência da doença foi de 1,27/10 mil habitantes (equivalente a 25.738 indivíduos em tratamento) e o coeficiente de detecção geral de 15,32/100 mil habitantes (31.064 casos novos). Para o Programa Nacional de Controle da Hanseníase, a detecção de casos de hanseníase entre menores de 15 anos é a prioridade da política atual de eliminação da doença como problema de saúde pública, por sinalizar focos de infecção ativos e transmissão recente. Em 2014, foram notificados 2.341 casos novos e o coeficiente de detecção foi de 4,88/ 100 mil habitantes, neste $\begin{array}{llll}\text { grupo etário } & \text { (Disponível }\end{array}$ <http://portalsaude.saude.gov.br/images/pdf/2015/julho/27/Dados-2014---final.pdf> e <http://portalsaude.saude.gov.br/images/pdf/2015/outubro/29/S--rie-Hist--rica-Hansen-ase-2000---2014.pdf> Acesso em 14/06/2016). Entretanto, a prevalência de hanseníase ainda apresenta importantes variações regionais e estaduais. Nas regiões Norte, Nordeste e Centro-Oeste, (exceto Rio Grande do Norte e Distrito Federal) ainda há coeficientes elevados, sobretudo nos estados do Mato Grosso, Tocantins, Maranhão, Rondônia e Pará (BRASIL, 2014a).

Os números percentuais de cura e de grau de incapacidade física ao diagnóstico são considerados regulares no Brasil, de acordo com os parâmetros oficiais. Embora a incidência tenha reduzido nos últimos anos, a taxa de detecção permanece com números bastante semelhantes, demonstrando que há um longo caminho a percorrer, principalmente barrar a transmissão de casos já existentes e reduzir as incapacidades adquiridas (BRASIL, 2014b).

Quanto ao recorte raça/cor, em 2010 o coeficiente de detecção de casos novos de hanseníase na população negra (pretos e pardos) foi de 23,62/100.000 hab., 
correspondendo a 22.863 casos novos, enquanto que para a população geral do país foi de 18,22/100.000 hab. (34.894 casos novos). Esses coeficientes correspondem, respectivamente, a parâmetros de endemicidade muito alto e alto. A proporção de casos na população negra entre os casos novos diagnosticados foi de $65,5 \%$. O percentual de cura nas coortes de casos novos na população negra foi de $79 \%$ e na população geral, incluindo todas as entradas de raça/cor, foi de $82,6 \%$ (BRASIL, 2014b).

O Brasil mantém, nas últimas décadas, a situação mais desfavorável na América e o diagnóstico da segunda maior quantidade de casos do mundo, depois da Índia. Entre as premissas sociais associadas à distribuição geográfica da doença, reafirmam-se a pobreza, a desnutrição ou algumas carências nutricionais, além de condições higiênicas desfavoráveis e movimentos migratórios. A doença relaciona-se a indicadores como baixa renda familiar ou per capita, baixa escolaridade e falta de condições básicas de saúde (MAGALHÃES, 2007).

\section{JUSTIFICATIVA}

A hanseníase caracteriza-se por ter um forte componente social na sua determinação atingindo em especial os grupos mais pobres da sociedade. Nesse contexto faz-se importante avaliar os múltiplos reflexos da enfermidade e do seu tratamento na vida das pessoas acometidas. Ressalta-se também que os estudos da enfermidade estão concentrados nos aspectos clínicos e no perfil socioeconômico da doença, assim o estudo visa cobrir uma lacuna no sentido mais amplo dessa doença.

É uma enfermidade que associa as dimensões física, psicológica e sociocultural. Também possui histórico de estigmatização, preconceito, isolamento social, sequelas e desagregação familiar.

O longo tempo de tratamento também pode prejudicar e interferir no tratamento das doenças. A administração de um conjunto de fármacos que devem ser tomados corretamente para obter a cura, efeitos adversos dos medicamentos e a necessidade de autocuidados, autoconhecimento corporal para identificar possíveis alterações ou recidiva, como no caso da hanseníase, dificultam a cura e adesão dos doentes a esse tratamento (BRASIL, 2002).

Sabe-se que as taxas de abandono dos tratamentos das doenças negligenciadas 
são altas; vários estudos já foram realizados nesse sentido. Algumas das causas mais comumente relatadas são dificuldades financeiras dos usuários, estigma e preconceito, aspectos sociais próprios da doença, falta de apoio familiar, a medicação empregada, sua alta complexidade, efeitos colaterais e duração do tratamento; desconhecimento do curso da doença pelos usuários e nível de escolaridade destes; descrença dos pacientes na terapêutica empregada; obstáculos geográficos, socioeconômicos e trabalhistas enfrentados por estes (BARATA, 2000; FOGOS, 2000; IGNOTTI, 2001; WHO, 2001).

Assim, para compreendermos melhor o gerenciamento da hanseníase no cotidiano das pessoas, o impacto da doença em suas vidas e as possíveis motivações que fazem com que essa enfermidade seja persistente no Brasil, empreendemos uma pesquisa de natureza qualitativa e que pretende conferir protagonismo ao discurso aos próprios pacientes.

No Brasil, na segunda metade dos anos 1980, os movimentos sociais, como o da Reforma Sanitária, adotaram como matriz o pensamento gramsciniano. Desde Asa Laurell, que tematizava o processo saúde-doença, essa matriz tomou de assalto o pensamento em saúde e vem desenvolvendo uma abordagem na qual a equidade e a desigualdade em saúde têm sido contrapostas.

Com o sucesso do movimento sanitário, a sociedade civil logrou inscrever na Constituição de 1988 a ideia de que a saúde é um direito máximo e consagrado na lei constitucional. A Constituição Federal deixou clara tal orientação em seu artigo 196:

A saúde é direito de todos e dever do Estado, garantido mediante políticas sociais e econômicas que visem à redução do risco de doença e de outros agravos e ao acesso universal e igualitário às ações e serviços para sua promoção, proteção e recuperação. (grifo nosso)

A Lei 8.080, de 19 de setembro de 1990, dispõe no seu artigo $3^{\circ}$ :

Os níveis de saúde expressam a organização social e econômica do País, tendo a saúde como determinantes e condicionantes, entre outros, a alimentação, a moradia, o saneamento básico, o meio ambiente, o trabalho, a renda, a educação, a atividade física, o transporte, o lazer e o acesso aos bens e serviços essenciais. (grifo nosso)

A visão de saúde não pode se dar de forma isolada das condições que cercam o 
indivíduo e a coletividade. Segundo Santos (2005), mesmo que o sistema de saúde tenha atuação preventiva e curativa absolutamente iguais, as pessoas que vivem em situação precária fatalmente serão mais acometidas de doenças e outros agravos, ainda que o sistema de saúde lhes ofereça um serviço de recuperação. Daí dizer-se que, sem redução das desigualdades sociais, sem a erradicação da pobreza e a melhoria do modo de vida, o setor saúde será o estuário de todas as mazelas das más políticas sociais e econômicas. E, sem essa garantia de mudança dos fatores condicionantes e determinantes, não se estará garantindo o direito à saúde, em sua abrangência constitucional.

A compreensão das diferenças e desigualdade em saúde exige análise ao mesmo tempo ampla e aprofundada. Para tal, é importante aportar conhecimentos de outras disciplinas. Um dos campos que mais pode contribuir, por estudar a vida social humana, dos grupos e das sociedades, permitindo compreender, interpretar e explicar questões sociais, é a Sociologia da Saúde.

A hanseníase pode atingir qualquer classe social, mas sua incidência é maior nos segmentos mais empobrecidos da população, devido à presença de condições socioeconômicas desfavoráveis, com condições de vida e de saúde precárias, o que facilita a contaminação e a propagação do bacilo (LOPES E RANGEL, 2014).

\section{MARCO TEÓRICO}

$\underline{\text { Aspectos sociais e culturais: a hanseníase como enfermidade }}$

\section{Estigma}

A sociedade estabelece um modelo de categorias e tenta catalogar as pessoas conforme os atributos considerados comuns e naturais pelos membros dessa categoria. Estabelece também as categorias a que as pessoas devem pertencer, bem como os seus atributos, o que significa que a sociedade determina um padrão externo ao indivíduo que permite prever a categoria e os atributos, a identidade social e as relações com o meio. O indivíduo com um comportamento diferente do grupo seria excluído, pois não se enquadraria nas características esperadas pela comunidade. O termo estigma faz 
referência a um atributo profundamente depreciativo e, devido a este atributo, acaba-se fazendo vários tipos de discriminações. Constrói-se uma teoria do estigma, uma ideologia para explicar a inferioridade e racionalizando uma animosidade baseada em outras diferenças, tais como as de classe social (GOFFMAN, 1980).

As pessoas com algum tipo de diferença que induz uma dificuldade em sua aceitação na sociedade são portadoras de estigma. O estigma é um atributo que produz um amplo descrédito na vida do sujeito, em algumas situações pode ser definido como "defeito", "falha" ou desvantagem em relação ao outro, produzindo uma discrepância entre a identidade social virtual e a identidade real. Para os estigmatizados, a sociedade reduz as oportunidades, não atribui valor, impõe a perda da identidade social e determina uma imagem deteriorada, de acordo com o modelo que convém à sociedade.

O enfrentamento das questões inerentes ao estigma em hanseníase amplia a possibilidade de eficácia da prevenção e dos programas de cuidados aos portadores encorajando as pessoas a buscarem o diagnóstico e a procurar informações sobre como se cuidarem e aos outros. Além disso, tem um impacto positivo nas comunidades desfavorecidas, já estigmatizadas e marginalizadas, bem como fortalece a noção de direitos humanos fundamentais, em particular o direito a viver sem ser discriminado (RAMOS JÚNIOR ET AL., 2014).

\section{Conceitos de Bourdieu}

Pierre Bourdieu foi um dos grandes sociólogos do século XX, sua obra se deu em diferentes campos das Ciências Sociais, além de religião, artes, escola, linguagem, mídia, alta costura, gosto, dentre outros. Para compreender a teoria sociológica de Bourdieu, serão abordados os conceitos de habitus, campo e capital.

Uma das mais importantes questões na obra de Bourdieu se centraliza na análise de como os agentes incorporam a estrutura social, ao mesmo tempo em que a produzem, legitimam e reproduzem.

O princípio de produção, incorporado nos próprios sujeitos, denomina-se habitus e é entendido como um sistema de disposições duráveis estruturadas de acordo com o meio social dos sujeitos e que seriam predispostas a funcionar como estruturas 
estruturantes, isto é, como princípio gerador e estruturador das práticas e das representações (BOURDIEU, 1983).

O habitus é concebido como um sistema de esquemas individuais, socialmente constituído de disposições estruturadas (no social) e estruturantes (nas mentes), adquirido nas e pelas experiências práticas (em condições sociais específicas de existência), constantemente orientado para funções e ações do agir cotidiano (SETTON, 2002).

O argumento de Bourdieu é o de que a estruturação das práticas sociais não é um processo que se faça mecanicamente, de fora para dentro, de acordo com as condições objetivas presentes em determinado espaço ou situação social. Não seria um processo conduzido de forma autônoma, consciente e deliberada pelos sujeitos individuais. As práticas sociais seriam estruturadas, isto é, apresentariam propriedades típicas da posição social de quem as produz, porque a própria subjetividade dos indivíduos, sua forma de perceber e apreciar o mundo, suas preferências, seus gostos, suas aspirações, estariam previamente estruturadas em relação ao momento da ação (NOGUEIRA, 2004).

Bourdieu define o habitus de classe como uma estrutura construída socialmente por herança familiar e afetiva, passada de geração a geração por imperceptíveis heranças emocionais e morais familiares, para indicar um comportamento social que nada tem a ver com "intenções" ou "racionalizações" explícitas. Ainda que o habitus possa ser modificado no decorrer da trajetória individual, ele também estabelece limites e possibilidades para essas mudanças possíveis (SOUZA, 2009).

Bourdieu (1983) argumenta que cada sujeito, em função de sua posição nas estruturas sociais, vivenciaria uma série característica de experiências que estruturariam internamente sua subjetividade, constituindo uma espécie de "matriz de percepções e apreciações" que orientaria, estruturaria, suas ações em todas as situações subsequentes. Essa matriz, ou seja, o habitus, não corresponderia a um conjunto inflexível de regras de comportamento a ser indefinidamente seguidas pelo sujeito, mas, diferentemente disso, constituiria um "princípio gerador duravelmente armado de improvisações regradas". O habitus seria formado por um sistema de disposições gerais que precisariam ser adaptadas pelo sujeito a cada conjuntura específica de ação. Bourdieu afirma que o 
habitus seria fruto da incorporação da estrutura social e da posição social de origem no interior do próprio sujeito. A posição de cada sujeito na estrutura das relações objetivas propiciaria um conjunto de vivências típicas que tenderiam a se consolidar na forma de um habitus adequado à sua posição social. Esse habitus, por sua vez, faria com que esse sujeito agisse nas mais diversas situações sociais não como um indivíduo qualquer, mas como um membro típico de um grupo ou classe social que ocupa uma posição determinada nas estruturas sociais. Ao agir dessa forma, o sujeito colaboraria, sem o saber, para reproduzir as propriedades do seu grupo social de origem e a própria estrutura das posições sociais na qual ele foi formado (NOGUEIRA, 2004).

O conceito de habitus permite a Bourdieu sustentar a existência de uma estrutura social objetiva, baseada em múltiplas relações de luta e dominação entre grupos e classes sociais - das quais os sujeitos participam e para cuja perpetuação colaboram através de suas ações cotidianas, sem que tenham plena consciência. A convicção de Bourdieu é a de que as ações dos sujeitos têm um sentido objetivo que lhes escapa, eles agem como membros de um grupo social específico mesmo quando não possuam consciência clara disso. As marcas de sua posição social, os símbolos que a distinguem e que a situam na hierarquia das posições sociais, as estratégias de ação e de reprodução que lhe são típicas, as crenças, os gostos, as preferências que a caracterizam, em resumo, as propriedades correspondentes a uma posição social específica são incorporadas pelos sujeitos tornando-se parte da sua própria natureza. Os sujeitos não precisariam ter uma visão de conjunto da estrutura social e um conhecimento pleno das consequências objetivas de suas ações, particularmente, no sentido da perpetuação das relações de dominação, para decidirem ou não a agir de acordo com sua posição social. Eles simplesmente agiriam de acordo com o que aprenderam ao longo de sua socialização no interior de uma posição social específica (ARAÚJO, 2009).

\section{Adaptação dos conceitos de Bourdieu à realidade brasileira}

O sociólogo Jessé Souza adapta os conceitos de Bourdieu para a realidade brasileira. Segundo Souza (2009), o processo de modernização do Brasil, produziu uma classe inteira de indivíduos sem capital cultural nem econômico, desprovida de precondições sociais, morais e culturais que permitem a apropriação desses capitais ao 
longo da vida. O autor designou esta classe social de "ralé" estrutural. É uma classe de indivíduos precarizados, esquecida enquanto classe e com uma gênese e um destino comum. Logo, o principal argumento defendido por Souza (2009) é o de que os indivíduos mais pobres constituem uma classe social própria, com um habitus específico e bastante diverso daqueles das classes média e alta da população.

Souza (2009) argumenta que o habitus implica um conjunto de predisposições psicossociais, refletindo, na esfera da personalidade, a presença da economia emocional e das pré-condições cognitivas para um desempenho adequado ao atendimento das demandas do papel de produtor, com reflexos diretos no papel de cidadão. A ausência dessas pré-condições, em alguma medida significativa, implica a constituição de um habitus marcado pela precariedade. Por exemplo, a ausência de um emprego regular não acarreta apenas a falta de uma renda segura no fim do mês, mas também todo um sistema de organização coerente do tempo e da vida. A desorganização e a desestruturação sistêmica abrangem todas as dimensões da vida, o que ajuda a explicar também os altos índices de alcoolismo e de desestruturação familiar. Como as necessidades primárias não são do tipo que se possa adiar, todo o dia presente é vivido sem referência ao dia seguinte.

Indivíduos socializados num contexto de habitus precário não tiveram os prérequisitos mínimos para tornarem-se aptos ao exercício de funções sociais valorizadas pois não incorporaram as formas de pensar e agir necessárias para alcançar qualificação profissional, auto-respeito e estima social (SOUZA, 2009).

\section{$\underline{\text { Habitus }}$ e Corpo}

Souza (2006) cita uma leitura que Bourdieu faz da internalização de valores, cuja ênfase é no condicionamento pré-reflexivo, automático, emotivo, espontâneo, ou seja, "inscrito no corpo" das ações, disposições e escolhas do indivíduo. Souza utiliza a noção de habitus, pois considera que este permite enfatizar todo o conjunto de disposições culturais e institucionais que se inscrevem no corpo e que se expressam na linguagem corporal de cada indivíduo, transformando escolhas valorativas culturais e institucionais em carne e osso. Para Bourdieu é o conjunto de disposições ligadas a um estilo de vida peculiar que conformam o habitus estratificado por classes sociais e que legitimam, de forma invisível e subliminar, o acesso diferencial aos recursos materiais. 
No entanto, a parcela pré-reflexiva, automática do habitus não esgota, nem de longe, o significado do conceito. Esta parte automatizada, ainda que importante, representaria mais especificamente a hexis corporal. É um reducionismo oriundo de uma leitura pouco aprofundada, resumir a determinação das práticas sociais dos agentes a uma deteminação inconsciente e irrefletida. Boa parte do habitus, inclusive o corporal, permite e indaga ao agente de refletir sobre suas ações, e mais que tudo, implica em escolhas.

Le Breton (2011) afirma que o corpo é o vetor pelo qual a relação com o mundo é construída, através de atividades perceptivas, expressão dos sentimentos, cerimoniais dos ritos de interação, conjunto de gestos e mímicas, produção da aparência, jogos sutis da sedução, técnicas do corpo, exercícios físicos, relação com a dor e o sofrimento. O corpo passa a ser pensado como uma forma moldada pela interação social.

Como apontava Bourdieu, tudo acontece no corpo biológico, que é o suporte de uma construção identitária realizada pela estrutura social sobre o indivíduo, construção da qual o próprio indivíduo não é inteiramente sujeito. (MONTAGNER, 2006). De acordo com Bourdieu (2001), é preciso um corpo para ser incluído no mundo, mas não simplesmente um modo de inclusão material e espacial, mas sim, juntamente a esse suporte biológico e ao nome, a objetivação da relação entre um corpo e um símbolo que o identifica. Todo o aparato social de formação de uma identidade, ou de um indivíduo virá a se sedimentar sobre essa relação de tornar concreto um todo biográfico, pelo qual um indivíduo vive na sociedade e que acabam por sedimentar um habitus relacionado à história do indivíduo.

Ainda segundo Le Breton (2011), os seres humanos, por meio de suas representações simbólicas, retiram o corpo de uma postura objetal para inseri-lo como sujeito nas relações sociais. O corpo é o primeiro e mais natural instrumento do homem, evidenciando que o homem não é produto do corpo, mas sim, ele mesmo produz as qualidades do corpo na interação com os outros e na imersão no campo simbólico.

Bourdieu (2007), quando utiliza a noção de capital cultural, afirma que as propriedades corporais podem funcionar como capital para obtenção de lucros sociais, para conceder à representação dominante do corpo um reconhecimento incondicional. 


\section{Corpo, saúde e classe social}

Boltanski (1979) afirma que há uma barreira linguística que separa o médico do paciente das classes populares, pois a utilização de um vocabulário especializado redobra a distância linguística. Porém, não basta mostrar que o médico e o enfermo das classes populares não falam a mesma língua, as explicações dadas pelo médico variam em função da classe social do enfermo. Os médicos, em geral, não dão longas explicações senão àqueles que julgam bastante evoluídos para compreender o que vai lhes ser explicado. Para o médico, o enfermo das classes populares é um membro de uma classe inferior a sua, possui nível de instrução inferior e não tem condições de compreender a linguagem e as explicações do médico. É em função da imagem social que o médico definirá sua estratégia frente ao enfermo, de acordo com a classe social deste, e, fazendo com que este reconheça a autoridade do médico e aceite sua vontade, desapropriando-o de sua doença e até mesmo de seu corpo e sensações.

Deste modo, o enfermo faz uma seleção do discurso do médico retendo apenas os termos que reconhece, mesmo ignorando seu significado científico. Com esses poucos termos esparsos, o enfermo das classes populares vai tentar reconstruir um discurso coerente. $\mathrm{O}$ trabalho que estes indivíduos desenvolvem consiste em substituir a classificação científica por uma classificação em categorias simples feita com os meios de que dispõem, levando em conta as propriedades de aspecto imediato dos remédios. Distinguirão os medicamentos em função de sua apresentação ou da forma de administração (xaropes, pomadas, pílulas, injeções), tamanho (pequeno ou grande) e cor (BOLTANSKI, 1979).

Neste contexto, pode-se acrescentar ainda a acessibilidade sociocultural que se refere à apreciação dos fenômenos que determinam a busca de assistência à saúde como, por exemplo: percepção sobre o corpo e a doença, crenças relativas à saúde, tolerância à dor e credibilidade nos serviços de saúde, dentre outros (FEKETE, 1997).

Silveira (2009) destaca que o conceito de acessibilidade sociocultural enfoca a perspectiva da população e do sistema de saúde. A perspectiva da população refere-se tanto às crenças e hábitos quanto aos cuidados em saúde; a resistência a intervenções médicas, por motivo de medo ou vergonha; o nível de conhecimento sobre a oferta de serviços; a fraca participação dos usuários na organização dos serviços de saúde, dentre 
outros. Entretanto, também as instituições e os funcionários prefiguram este tipo de dificuldade de acesso quando não estão devidamente preparados para receber distintos perfis socioculturais de pacientes e quando a formação dos profissionais está desvinculada da realidade das condições de vida e saúde daqueles.

Os médicos e enfermos, mesmo pertencendo à mesma cultura, interpretam a relação saúde-doença de formas diferentes. A diversidade cultural é uma realidade com a qual os médicos precisam saber lidar em sua prática. Essa mesma diversidade faz com que o médico seja capaz de aprender novos valores e desenvolver outras percepções de saúde-doença. Dentre as dificuldades em lidar com os aspectos psicossociais, está a limitação em lidar com a dinâmica familiar e suas relações, os medos e ansiedades acerca da doença e seus sintomas. Muitas vezes os enfermos fazem referências a aspectos sociofamiliares, evidenciando a importância destes na sua condição de saúde. As percepções diferenciadas entre médicos e enfermos nos relacionamentos são influenciadas por questões que enfatizam a assimetria e dificultam o estabelecimento de uma melhor relação. Essa diferença é reafirmada pela compreensão da doença por parte do paciente, que perpassa por caminhos diversos daqueles do médico. A experiência da doença pelo enfermo envolve aspectos culturais, familiares e emocionais (CAPRARA e RODRIGUES, 2004).

A distância entre o risco sanitário corrido pelos agentes e os meios sanitários de prevenção contra este risco é bastante desigual nas diferentes classes sociais. Soma-se a isso a concepção de "comportamento" ou "disposição sanitária" distinta conforme a classe social do indivíduo, o que pressupõe inclusive a distinção de percepção das sensações mórbidas. Isto quer dizer que embora as sensações possam ser as mesmas, a intensidade com a qual elas são exprimidas varia de acordo com a classe social do paciente (BOLTANSKI, 1989).

A avaliação de políticas públicas destinadas às classes mais pobres, por não considerarem a especificidade de suas disposições e condições de vida, não conseguem contemplar, por um longo período de tempo, planos efetivos que sustentam a melhoria na qualidade de vida dessa população (SILVEIRA, 2009).

Bury (apud Montagner 2011) afirma que as transformações ocorridas no corpo em função de determinadas doenças podem provocar mudanças na identidade. Já 
Nettleton (apud Montagner 2011) afirma que poder confiar no "corpo normal" é uma das prerrogativas para a ação e interação sociais. Dependendo do grau da enfermidade e do sofrimento, a relação de reciprocidade não pode ser igualitária e pode haver um momento de dependência em relação ao outro.

Silveira (2009) ainda considera, sobre o conceito de Fekete, o efeito da diferenciação sociocultural entre usuários e profissionais de saúde que pode ser avaliado em termos de distinção de habitus de classe, compreendendo tal distinção como passível de propiciar um processo malsucedido de comunicação e entendimento entre ambos. Tal condição pode ser ainda intensificada, se levados em conta os padrões de violência simbólica desenvolvidos pelas classes dominantes sobre as classes inferiores, como forma de distinção e afastamento destas (BOURDIEU, 2007). Deste modo, os conflitos de classe tornam-se uma dimensão importante para o entendimento da acessibilidade sociocultural, ainda mais quando os indivíduos estão expostos a uma rotina emocional e fisicamente desgastante.

A educação em saúde, em geral, é oferecida como palestras ou conselhos fundamentados em comportamentos pensados por técnicos oriundos da classe média, que pouco compreendem a dinâmica e as condições de vida das classes mais pobres. Deste modo, o ideal seria refletir a saúde a partir da realidade em que as pessoas vivem e de acordo com as suas condições e interesses (PEREIRA et al, 2005).

De acordo com Caprara e Rodrigues (2004), o desenvolvimento da bioquímica, da farmacologia, da imunologia e da genética contribuiu para o crescimento de um modelo biomédico centrado na doença, diminuindo o interesse pela subjetividade do paciente. As novas e sofisticadas técnicas de diagnóstico assumiram um papel importante em detrimento da relação pessoal entre o médico e o paciente. A tecnologia foi se incorporando no exercício da profissão, o que acabou deixando de lado o aspecto subjetivo da relação médico-paciente. Enquanto os avanços tecnológicos evoluíam significativamente, não se percebiam mudanças correspondentes nas condições de vida, como também não se verificava o aperfeiçoamento das práticas de saúde, como práticas compostas pela comunicação, pela observação, pelo trabalho de equipe, por atitudes fundamentadas em valores humanitários sólidos.

O modelo fragmentado do indivíduo subestima a dimensão psicológica, social e 
cultural da relação saúde-doença, com os significados que a doença assume para o paciente e seus familiares. O médico não é ativamente estimulado a pensar o enfermo em sua totalidade, como um ser biopsicossocial, e a perceber o significado do adoecer para o paciente. Além dos aspectos culturais é necessário enfatizar que médicos e enfermos não se colocam no mesmo plano: trata-se de uma relação assimétrica em que o médico detém um corpo de conhecimentos do qual o paciente geralmente é excluído (ARROW apud CAPRARA E RODRIGUES, 2004).

Os corpos sofrem mudança por causa da doença crônica, e com eles o sentimento de corporeidade. As concepções sociais alteram-se em relação aos sentimentos experimentados, às alterações físicas e em relação aos próprios atos. $\mathrm{Na}$ experiência com a enfermidade, os aspectos biológicos são importantes, do mesmo modo que a ruptura coloca em relevo os recursos cognitivos e materiais à disposição das pessoas (BURY, 1982 apud MONTAGNER, 2011). Em relação à corporeidade, a experiência com a enfermidade é muito mais do que um aprendizado ou uma práxis, ela envolve a vida dos indivíduos em seus mais diferentes momentos históricos e biográficos.

Compreender como a pessoa articula as mudanças ocasionadas pela enfermidade e sentidas inicialmente em sua corporeidade é o primeiro passo para dimensionar a influência da enfermidade no cotidiano (MONTAGNER, 2011).

\section{Corpo, saúde e classe social no Brasil}

Souza (2009) chama a atenção para outras dimensões do problema da saúde pública para um melhor entendimento da maneira como os serviços alcançam os pacientes das classes populares. O autor afirma que é a falta de reconhecimento da cidadania que está implícita no tratamento desigual recebido pelas pessoas destas classes. A existência de acentuado número de indivíduos atingidos constantemente por doenças cria um modo de vida peculiar que, para além das limitações de suas condições materiais e culturais precárias, são acometidos pela maior privação de sua saúde.

Na história brasileira, a promoção da saúde foi mais eficiente em um grupo de pessoas, deixando outro grupo negligenciado. Assim, o efeito das políticas públicas no Brasil, por não tomar como princípio a existência da ralé precarizada enquanto classe, e 
levar em consideração suas necessidades singulares, é a não contemplação de suas demandas, causando negligência e manutenção de contingentes populacionais sem acesso aos serviços de saúde. As implicações dessa realidade podem ser observadas nas doenças negligenciadas e, sobretudo, nos incontáveis episódios de maus-tratos e descaso aos pacientes das classes pobres (SOUZA, 2009).

Parece ficar implícito na prática médica que o importante é apenas salvar a vida do paciente da ralé, não interessando as demandas sociais e psicológicas, já que o paciente nada mais é que um corpo que médicos e enfermeiros são pagos para tratar. Tem-se com isso uma noção animalizada sobre a vida e a saúde, algo que os princípios do SUS combatem. Assim, o esquecimento da ralé enquanto classe é reproduzido pelas falhas dessas instituições e o "SUS real", ao se distanciar do "SUS constitucional", reitera a desigualdade que retira da ralé o controle e o poder sobre sua própria vida (SOUZA, 2009).

A relação médico-paciente é baseada na confiança que o médico inspira e na compreensão do médico sobre a realidade do indivíduo, o que exige paciência, atenção e interesse, deste modo, o médico que deseja uma relação construtiva com o paciente deve escutá-lo com atenção (PEREIRA et al 2005).

\section{Ruptura Biográfica}

Michael Bury realizou uma pesquisa na Inglaterra, utilizando o conceito de ruptura biográfica, com enfermos com diagnóstico precoce de artrite reumatoide. Os estudos do autor tinham como objetivo explorar os problemas de reconhecimento e mudanças na vida e nos relacionamentos ocasionados pela descoberta da doença. Percebendo uma "bifurcação" na vida das pessoas, uma diferença entre o antes e o depois, o autor propôs como resultado o conceito de ruptura biográfica como instrumento de análise, o que lhe permitiu descrever o que acontecia na vida dessas pessoas após o diagnóstico.

O ponto de vista de Bury (2011) é que a doença, especialmente a crônica, é o tipo de experiência em que as estruturas da vida cotidiana e as formas de conhecimento se rompem. Essa ruptura realça os recursos cognitivos e materiais disponíveis aos 
indivíduos, exibe as principais formas que as explicações para a dor e o sofrimento vivenciados na doença assumem na sociedade moderna, a continuidade e a descontinuidade dos modos de pensamento profissional e leigo e as fontes de variabilidade da experiência originada da influência das restrições estruturais sobre a habilidade de adaptação.

As maneiras de encarar e resolver o cotidiano são resultado da inter-relação da pessoa com o seu meio social e cultural. As características das enfermidades de longa duração sempre afetam a pessoa em sua nova condição porque este tipo de enfermidade traz mudanças fundamentais no estilo de vida. Na perspectiva da ruptura biográfica, a enfermidade é uma espécie de experiência de ruptura e deve ser tomada como uma situação crítica na vida da pessoa e que desestabiliza a sua interpretação da realidade. (MONTAGNER, 2011)

Bury (2011) conecta três aspectos da ruptura. Primeiramente, a ruptura de pressuposições e comportamentos dados como certos. É o estágio do questionamento, envolve atenção aos estados corporais que nem sempre são trazidos à consciência e decisões sobre procurar ajuda. Em segundo lugar, há rupturas mais profundas nos sistemas explanatórios que são normalmente usados pelas pessoas, de tal maneira que uma revisão fundamental da biografia e do autoconceito da pessoa está envolvida. Em terceiro lugar, há a reação à ruptura, envolvendo a mobilização de recursos, no enfrentamento de uma situação alterada. Ocupação e classe social estão intimamente relacionadas, embora sua relação na doença seja um assunto complexo. A importância da classe social reside na distribuição variável dos recursos na sociedade, assim como a habilidade de indivíduos de diferentes estratos sociais em compensar os efeitos da incapacidade e assim contrabalançar deficiências econômicas e de outros tipos. A ruptura da reciprocidade, os problemas na legitimação da mudança de comportamento e os efeitos gerais do estigma associado à doença crônica afetam a habilidade do indivíduo de mobilizar recursos favoravelmente.

Bury (apud Montagner 2011) distingue três aspectos da experiência ao tratar do conceito de enfermidade crônica: a ruptura biográfica, o impacto do tratamento na vida dos pacientes e a adaptação e o enfrentamento na busca de reconstruir a normalidade no cotidiano procurando entender as relações entre a enfermidade e a sociedade. Bury também elenca três aspectos da ruptura biográfica para os posteriores desdobramentos 
da enfermidade crônica. Na primeira fase da ruptura biográfica, há uma quebra das crenças e comportamentos cotidianos. Na segunda fase há um repensar fundamental da biografia pessoal e da autoimagem envolvida, e então será retrabalhada a identidade.

A trajetória social é o resultado construído de um sistema de traços pertinentes de uma biografia individual ou de um grupo, é o movimento dentro de um campo definido estruturalmente. Deste modo, a trajetória social é uma maneira singular de percorrer o espaço social, onde se exprimem as disposições do habitus. Ao se analisar a experiência da pessoa portadora de determinada enfermidade, deve ser ressaltada a centralidade da ação no seu mundo cotidiano, nas maneiras de organizar e gerenciar a enfermidade (MONTAGNER, 2007).

Deve-se considerar as características da enfermidade, suas limitações e estigmas, como o corpo responde a determinados tratamentos, como a pessoa analisa e processa as informações que recebe sobre sua doença ou por quais fontes ela obtém estas informações. Sobretudo considerar que as ações das pessoas também estão condicionadas pela ajuda e pelo apoio ou falta de apoio familiar e social, que receberam em algum momento e as interferências geradas em suas estratégias pessoais. Logo, na perspectiva de Bury, a tentativa das pessoas enfermas é buscar estratégias de reorganização da vida prática que deem um novo sentido para suas vidas (MONTAGNER, 2011).

O processo de reestruturação da resposta individual aos problemas advindos da doença crônica deve ser situado tanto no contexto social quanto no cultural. Pensá-la como um episódio disruptivo na vida do indivíduo permite analisar o impacto causado pelas mudanças no corpo e pelos sintomas na situação de vida e em suas relações sociais. Ao mesmo tempo em que a enfermidade crônica altera a história do sujeito, independente dele refletir ou não sobre sua condição, ela também faz com que a vida do paciente seja reconstruída com base em suas estratégias e habilidades para lidar com a doença e para refazer novas redes de suporte e apoio social (MONTAGNER, 2011).

A hanseníase gera várias mudanças na vida do indivíduo, desde o aceitar-se como doente até a convivência com o preconceito e a discriminação, com sequelas físicas e emocionais. O indivíduo precisa ressignificar-se e aprender a conviver com atitudes discriminatória e adaptar-se a uma nova imagem corporal que se altera, o que 
acaba interferindo em sua autoestima (EIDT,2000).

Montagner (2011) resume que a experiência com o adoecimento promove uma ruptura ou descontinuidade na vida do indivíduo. A estrutura da vida diária deverá ser revista, reestruturada e planejada de acordo com uma nova realidade que pressuponha novas atitudes e comportamentos.

Para Eidt (2000), contrair hanseníase não é apenas contrair uma doença, mas é assumir uma nova identidade, que atinge não apenas a parte física do doente, mas a totalidade do ser humano. Assim, o combate à hanseníase deve ser acompanhado pela cura do doente na sua totalidade e não apenas pela eliminação do seu agente causador.

Portanto, a interrupção do cotidiano por uma doença crônica talvez seja a principal característica da experiência, pois é nessa interrupção que observaremos aflorar a inter-relação entre o corpo e a coletividade. Uma vez que a perspectiva do doente é crucial, a forma como ele vive a sua ruptura biográfica é fundamental. Compreender suas ações também significará entender seus condicionamentos, suas representações e os recursos de que a pessoa dispõe (MONTAGNER, 2011).

\section{OBJETIVOS}

\subsection{Objetivo geral}

Analisar a experiência com a enfermidade de pessoas com hanseníase, atendidas em um ambulatório especializado em hanseníase do Hospital Universitário de Brasília, em especial, como essas pessoas vivenciam a doença e o tratamento em seus corpos e em suas relações sócio familiares e profissionais.

\subsection{Objetivos específicos}

1. Conhecer o perfil social das pessoas atendidas no HUB.

2. Conhecer as dificuldades encontradas no controle, prevenção e tratamento da hanseníase sob a perspectiva das pessoas atendidas na rede pública de saúde do DF. 
3. Conhecer a relação do indivíduo com seu corpo, com a doença e suas consequências, e compreender se ocorre ruptura biográfica após o diagnóstico de hanseníase.

\section{METODOLOGIA}

A população entrevistada foi de pesssoas que utilizam o serviço público de saúde do Hospital da Universidade de Brasília (HUB), no Distrito Federal, para acompanhamento e tratamento da hanseníase.

As entrevistas foram realizadas com o apoio de um roteiro em forma de perguntas semiestruturadas, preconizado em pesquisa social. Conforme Minayo (2002), através da entrevista o pesquisador busca obter informações na fala dos atores sociais. As entrevistas, orientadas por um roteiro inicial, possibilitaram certa liberdade na argumentação dos entrevistados.

O questionário foi dividido em categorias: dados pessoais, início da doença, medicação, satisfação com o atendimento, preconceito, dificuldades e mudanças após o diagnóstico.

A análise dos dados foi feita através da análise temática. Para Bardin (2011), a análise temática é uma das formas que melhor se aplica à pesquisa qualitativa. A autora ainda propõe três etapas que constituem a aplicação dessa técnica:

a) Pré-análise: é a realização da "leitura flutuante", cujo objetivo é conhecer o material que será analisado.

b) Exploração do material: faz-se o recorte do texto classificando-os em categorias temáticas.

c) Tratamento dos resultados e interpretação: de posse dos resultados, o analista pode propor inferências e interpretações, respondendo às questões da pesquisa ou outras descobertas inesperadas.

Conforme Minayo (1994), a análise de conteúdo possui duas funções principais, a primeira é a verificação de hipóteses, quando se encontram respostas para as questões formuladas, confirmando-se ou não estas hipóteses. A outra função é a descoberta do 
que está por trás dos conteúdos manifestos, indo além das aparências do que está sendo comunicado. Godoy (1995) concorda com esta afirmativa, dizendo que o analista tem esforço duplicado: entender o sentido da comunicação, como se fosse o receptor normal, e, desviar o olhar, buscando outra significação, outra mensagem, passível de se enxergar por meio ou ao lado da primeira.

Bardin (2011) designa a análise de conteúdo como:

Conjunto de técnicas de análise das comunicações visando a obter, por procedimentos sistemáticos e objetivos de descrição do conteúdo das mensagens, indicadores que permitam a inferência de conhecimentos relativos às condições de produção/recepção (variáveis inferidas) destas mensagens.

Godoy (1995) orienta que cabe ao pesquisador, na fase da análise documental, ler os documentos selecionados e adotar procedimentos de codificação, classificação e categorização. Supondo que a unidade de codificação tenha sido a palavra, o próximo passo será classifica-la em blocos que expressem determinadas categorias, que confirmam ou modificam aquelas presentes nas hipóteses e referenciais teóricos propostos inicialmente.

Realizamos todas as etapas propostas por Minayo, chegando progressivamente às seguintes categorias: habitus, ruptura biográfica, estigma/preconceito e relação com o corpo, que serão explicitadas na discussão.

\subsection{Características do local de estudo}

O Hospital Universitário de Brasília (HUB) conta com um Ambulatório Especializado em Dermatologia que atende pessoas encaminhadas das Unidades Básicas de Saúde. Este atendimento ocorre semanalmente sempre às quartas-feiras pela manhã, juntamente com os pacientes com pênfigo. Os indivíduos são agendados, mas o atendimento pelos médicos e residentes é por ordem de chegada. $\mathrm{O}$ atendimento começa em torno das $8 \mathrm{~h}$ e 30 minutos. Muitos chegam antes das 7 horas, outros vêm de outros estados somente para a consulta. São agendados em média, 10 a 15 pacientes por semana. Há um grupo de voluntárias que oferece um café da manhã para os pacientes que estão aguardando a consulta. Há uma sala de enfermagem onde os pacientes em 
tratamento com poliquimioterapia (PQT) tomam a medicação mensal supervisionada, retiram a medicação e são acompanhados e orientados pela enfermeira responsável. São 2 médicos e em torno de 3 médicos residentes que atendem as pessoas agendadas. Há também clínica de fisioterapia. As entrevistas foram realizadas em uma sala que é utilizada como biblioteca pelos médicos e residentes.

\subsection{Critérios de inclusão}

Foram incluídos os indivíduos que se encontravam em tratamento no HUB, maiores de 18 anos. As entrevistas foram realizadas de acordo com a ordem de chegada, enquanto aguardavam a consulta médica.

\subsection{Questões éticas}

O presente estudo foi aprovado pelo Comitê de Ética da Faculdade de Ciências da Saúde da Universidade de Brasília, com número do CAAE 43863514.0.0000.0030, parecer número 1.253.029, emitido em 30 de setembro de 2015.

O estudo contemplou todos os aspectos éticos contidos na Resolução no 466, de 12 de dezembro de 2012, assegurando os direitos e deveres que dizem respeito à comunidade científica, aos sujeitos da pesquisa e ao Estado.

\section{RESULTADOS}

\section{Perfil dos entrevistados}

Foram feitas entrevistas com 27 pessoas em tratamento no HUB, selecionados ao acaso enquanto aguardavam a consulta médica, tratando-se assim de uma amostra de conveniência. Os pacientes encontravam-se nos mais variados estágios de tratamento da hanseníase: alguns já estavam em acompanhamento há anos, alguns em tratamento medicamentoso e outros nas consultas iniciais. No quesito renda, alguns pacientes informaram em valores e outros em salários mínimos, para padronizar, os valores foram colocados todos em salários mínimos. As entrevistas foram realizadas de setembro de 
2015 a março de 2016.

Por se tratar de uma doença citada na Bíblia, atribui-se nomes bíblicos aos entrevistados. Os nomes foram dados aleatoriamente aos pacientes, conforme a tabela 1.

Tabela 1 - Perfil dos entrevistados.

\begin{tabular}{|l|l|l|l|l|}
\hline NOME & SEXO & IDADE & RAÇA/COR & RESIDÊNCIA \\
\hline Ália & F & 53 & parda & MA \\
\hline Bartolomeu & M & 62 & pardo & GO \\
\hline Betsabé & F & 38 & preta & DF \\
\hline Disa & F & 42 & parda & DF \\
\hline Elias & M & 36 & preto & GO \\
\hline Esdras & M & 29 & negro & DF \\
\hline Ester & F & 54 & branca & MG \\
\hline Isaque & M & 39 & pardo & PA \\
\hline Jesabel & F & 59 & parda & DF \\
\hline Joabe & M & 53 & pardo & DF \\
\hline Lael & M & 39 & pardo & GO \\
\hline Lia & F & 64 & branca & DF \\
\hline Lídia & F & 56 & parda & DF \\
\hline Misael & M & 32 & pardo & DF \\
\hline Olímpia & F & 44 & parda & GO \\
\hline Palmira & F & 28 & parda & DF \\
\hline Raquel & F & 31 & parda & DF \\
\hline Rebeca & F & 38 & parda & PI \\
\hline Rute & F & 23 & parda & DF \\
\hline Safira & F & 59 & preta & GO \\
\hline Salma & F & 56 & parda & DF \\
\hline Salomé & F & 33 & parda & GO \\
\hline Samuel & M & 62 & preto & GO \\
\hline Saulo & M & 59 & pardo & DF \\
\hline Tamar & F & 35 & parda & BA \\
\hline Uriel & F & 59 & pardo & PI \\
\hline Zora & 33 & parda & DF \\
\hline & & & & \\
\hline & F & & \\
\hline
\end{tabular}

Dos 27 entrevistados, $22(81,48 \%)$ estavam em acompanhamento; dois $(7,4 \%)$ estavam tomando a medicação PQT; dois $(7,4 \%)$ iniciando o tratamento no momento da entrevista e estavam ali para a segunda ou terceira consulta, não podendo contribuir muito acerca das dificuldades e preconceitos. A maioria, 22 pacientes $(81,48 \%)$, relatou ter sequela ou alguma dificuldade e apenas dois $(7,4 \%)$ afirmaram não ter nenhuma 
sequela da doença.

\section{Características demográficas e socioeconômicas}

A maioria, 14 pessoas $(51,85 \%)$ reside no DF, sete $(25,92 \%)$ residem em Goiás, dois $(7,4 \%)$ no Piauí, os demais vêm dos seguintes estados para fazer o acompanhamento: Bahia, Maranhão, Minas Gerais, e Pará, todos com um paciente $(3,7 \%)$.

Tabela 2 - Distribuição dos entrevistados segundo Estado de residência.

\begin{tabular}{llr}
\hline $\begin{array}{l}\text { Estado de } \\
\text { residência }\end{array}$ & $\mathrm{N}$ & $\%$ \\
\hline $\begin{array}{l}\text { Distrito } \\
\text { Federal }\end{array}$ & 14 & 51,85 \\
Goiás & 7 & 25,93 \\
Piauí & 2 & 7,41 \\
Bahia & 1 & 3,70 \\
Maranhão & 1 & 3,70 \\
Minas Gerais & 1 & 3,70 \\
\hline Pará & 1 & 3,70 \\
\hline Total & 27 & 100 \\
\hline
\end{tabular}

A maioria dos entrevistados, 17 (63\%), é do sexo feminino e 10 (37\%) são do sexo masculino, conforme tabela 3 .

Tabela 3 - Distribuição dos entrevistados segundo sexo.

\begin{tabular}{lcr}
\hline Sexo & N & $\%$ \\
\hline Feminino & 17 & 62,96 \\
\hline Masculino & 10 & 37,04 \\
\hline Total & 27 & 100 \\
\hline
\end{tabular}

Quanto à renda por família, 16 (59,26\%) recebem de 1 a 2 salários mínimos; um deles não tem renda $(3,7 \%)$; um possui renda de até 0,5 salário $(3,7 \%)$; sete recebem mais de 2 salários $(25,93 \%)$; dois $(7,41 \%)$ não declararam ou não souberam informar. Destes, um $(3,7 \%)$ dependia do bolsa família. 
Tabela 4 - Distribuição dos entrevistados segundo renda familiar.

\begin{tabular}{lrr}
\hline Renda por família & $\mathrm{N}$ & \multicolumn{2}{c}{$\%$} \\
\hline Sem renda & 1 & 3,70 \\
\hline$<0,5$ salário & 1 & 3,70 \\
\hline 1 a 2 salários & 16 & 59,26 \\
\hline$>$ 2 salários & 7 & 25,93 \\
\hline $\begin{array}{l}\text { Não declarada/não soube } \\
\text { dizer }\end{array}$ & 2 & 7,41 \\
\hline Total & 27 & 100,00 \\
\hline
\end{tabular}

No quesito número de pessoas por residência, 10 (37,04\%), residem em casas com três ou quatro pessoas; três $(11,11 \%)$ moram sozinhos; quatro $(14,81 \%)$ moram com mais alguém; oito $(29,63 \%)$ moram entre cinco e seis pessoas; e duas $(7,41 \%)$ moram numa residência com mais de seis pessoas.

Tabela 5 - Distribuição dos entrevistados segundo quantidade de pessoas morando por residência.

\begin{tabular}{lrr}
\hline Pessoas por residência & $\mathrm{N}$ & $\%$ \\
\hline Mora sozinho & 3 & 11,11 \\
\hline 2 pessoas & 4 & 14,81 \\
\hline 3 a 4 pessoas & 10 & 37,04 \\
\hline 5 a 6 pessoas & 8 & 29,63 \\
\hline Mais de 6 & 2 & 7,41 \\
\hline Total & 27 & 100 \\
\hline
\end{tabular}

Quanto à escolaridade: 13 têm ensino fundamental incompleto $(48,15 \%)$, dois com ensino fundamental completo $(7,41 \%)$, um com ensino médio incompleto $(3,7 \%)$, três com ensino médio completo $(11,11 \%)$, quatro têm ensino superior completo $(14,81 \%)$ e três $(11 \%)$ são analfabetos.

Tabela 6 - Distribuição dos entrevistados segundo escolaridade.

\begin{tabular}{lrr}
\hline Escolaridade & $\mathrm{N}$ & \multicolumn{1}{c}{$\%$} \\
\hline Analfabeto & 3 & 11,11 \\
\hline Fundamental incompleto & 13 & 48,15 \\
\hline Fundamental completo & 2 & 7,41 \\
\hline Ensino médio incompleto & 1 & 3,70 \\
\hline
\end{tabular}




\begin{tabular}{lrr}
\hline Ensino médio completo & 3 & 11,11 \\
\hline Ensino superior & 4 & 14,81 \\
\hline Total & 27 & 100 \\
\hline
\end{tabular}

No quesito raça/cor $21(77,77 \%)$ se autodeclararam pardos, quatro $(14,81 \%)$ pretos e dois $(7,41 \%)$ brancos.

Tabela 7 - Distribuição dos entrevistados segundo raça/cor

\begin{tabular}{lrr}
\hline Raça/cor & \multicolumn{1}{c}{$\mathrm{n}$} & \multicolumn{1}{c}{$\%$} \\
\hline Branco & 2 & 7,41 \\
\hline Pardo & 21 & 77,78 \\
\hline Preto & 4 & 14,81 \\
\hline Total & 27 & 100 \\
\hline
\end{tabular}

A idade variou de 23 a 64 anos, sendo 10 (37\%) com idades entre 30 e 40 anos; três $(11,11 \%)$ entre 20 e 30 anos; dois $(7,41 \%)$ entre 40 e 50 anos e três $(11,11 \%)$ com mais de 60 anos de idade no momento da entrevista.

Tabela 8 - Distribuição dos entrevistados segundo faixa etária.

\begin{tabular}{lcr}
\hline IDADES & $\mathrm{n}$ & $\%$ \\
\hline Entre 20-30 anos & 3 & 11,11 \\
\hline Entre 30-40 anos & 10 & 37,04 \\
\hline Entre 40-50 anos & 2 & 7,41 \\
\hline Entre 50-60 anos & 9 & 33,33 \\
\hline$>60$ anos & 3 & 11,11 \\
\hline Total & 27 & 100 \\
\hline
\end{tabular}

Quanto à ocupação profissional, quatro pacientes $(14,81 \%)$ trabalham na roça; quatro $(14,81 \%)$ em casa; quatro $(14,81 \%)$ são pedreiros; três $(11 \%)$ são aposentados ou pensionistas, dois $(7,41 \%)$ trabalham como domésticas; dois $(7,41 \%)$ trabalham como atendentes e dois $(7,41 \%)$ não trabalham. As outras profissões são representadas por um $(3,7 \%)$ cada uma, a seguir: professora, cantora, militar, açougueiro e um paciente está desempregado. Cabe ressaltar que apenas um $(3,7 \%)$ dos pacientes está aposentado devido à hanseníase e outro estava recebendo auxílio doença. 
Tabela 9- Distribuição dos entrevistados segundo ocupação profissional.

\begin{tabular}{lcr} 
Profissão & $\mathrm{n}$ & \multicolumn{1}{c}{$\%$} \\
\hline Aposentado/pensionista & 3 & 11,11 \\
\hline Roça & 4 & 14,81 \\
\hline Do lar & 4 & 14,81 \\
\hline Pedreiro & 4 & 14,81 \\
\hline Doméstica & 2 & 7,41 \\
\hline Atendente & 2 & 7,41 \\
\hline Desempregado & 1 & 3,70 \\
\hline Cantora & 1 & 3,70 \\
\hline Trabalha na prefeitura & 1 & 3,70 \\
\hline Professora & 1 & 3,70 \\
\hline Militar & 1 & 3,70 \\
\hline Não trabalha & 2 & 7,41 \\
\hline Açougueiro & 1 & 3,70 \\
\hline Total & 27 & 100 \\
\hline
\end{tabular}

\section{Características quanto à percepção dos sintomas iniciais}

Como sintomas iniciais da doença os mais comuns observados entre os indivíduos foram: manchas em 12 (44,44\%) pacientes; dormência em seis (22,22\%); nódulos ou caroços em cinco (18,51\%); fraqueza no corpo em dois $(14,81 \%)$; dores nas pernas e/ou nos braços em dois $(14,81 \%)$; inchaço nas pernas e/ou braços em quatro $(14,81 \%)$; febre em dois $(7,41 \%)$; fraqueza em dois $(7,41 \%)$; bolha ou ferida em dois (7,41\%); membros atrofiados em um (3,7\%); sangramento nasal em um $(3,7 \%)$ e falta de força em um paciente $(3,7 \%)$.

Tabela 10 - Distribuição dos entrevistados segundo sintomas iniciais.

\begin{tabular}{lrr} 
Sintomas iniciais & $\mathrm{n}$ & \multicolumn{2}{c}{$\%$} \\
\hline Mancha & 12 & 44,44 \\
\hline Dormência & 6 & 22,22 \\
\hline Nódulo/ caroço & 5 & 18,52 \\
\hline Dor & 4 & 14,81 \\
\hline Inchaço & 4 & 14,81 \\
\hline Febre & 2 & 7,41 \\
\hline Fraqueza & 2 & 7,41 \\
\hline Bolha, ferida & 2 & 7,41 \\
\hline
\end{tabular}




\begin{tabular}{lrr}
\hline Atrofia & 1 & 3,70 \\
\hline Sangramento nasal & 1 & 3,70 \\
\hline Não conseguia caminhar & 1 & 3,70 \\
\hline Total & 27 & 100 \\
\hline
\end{tabular}

As entrevistas mostraram que houve demora no diagnóstico ou tratamento incorreto em nove pacientes $(33,33 \%)$.

Tabela 11 - Distribuição dos entrevistados segundo tempo de diagnóstico.

\begin{tabular}{lrr}
\hline Como foi o diagnóstico? & $\mathrm{n}$ & $\%$ \\
\hline Rápido & 10 & 37,04 \\
\hline Demora e/ou tratamento errado & 9 & 33,33 \\
\hline $\begin{array}{l}\text { Não procurou atendimento, } \\
\text { mas diagnóstico foi rápido }\end{array}$ & 4 & 14,81 \\
\hline & & \\
Não lembra/não soube informar & 4 & 14,81 \\
\hline Total & 27 & 100 \\
\hline
\end{tabular}

\section{DISCUSSÃO}

O estudo foi dividido nas seguintes categorias de análise de conteúdo: habitus, ruptura biográfica, estigma/preconceito e corpo. Dentro dessas categorias, estão as áreas temáticas utilizadas no questionário semiestruturado: atendimento e diagnóstico, medicação, preconceito, relação com o corpo, dificuldades após o diagnóstico, deixou de fazer/algo mudou após o diagnóstico.

Estudos sobre determinação social promovem uma reflexão acerca da equidade e da integralidade na saúde, enfatizando a importância da articulação de saúde/doença à iniquidade social e a possíveis respostas públicas à questão, de acordo com determinado grupo social. A hanseníase, mesmo sendo uma doença com um bacilo causador, conhecido há quase 150 anos, faz refletir sobre as condições coletivas de vida, ultrapassando a perspectiva dos hábitos e atitudes individuais. É um complexo problema de saúde pública, que afeta um significativo contingente populacional. (LOPES E RANGEL, 2014). 


\section{Habitus}

Souza (2009) defende o argumento de que as pessoas em situação vulnerável no Brasil constituem uma classe social própria e com um habitus específico e bastante diverso daqueles das classes média e alta da população e denominando-os de ralé, para chamar a atenção para essa classe esquecida e invisível.

O conceito de Bourdieu aponta que a posição de classe e estamento de cada indivíduo na estrutura das relações objetivas propicia um conjunto de vivências típicas que tendem a se consolidar na forma de um habitus adequado à sua posição social. Esse habitus faria com que o sujeito agisse nas mais diversas situações sociais como um agente social com a interiorização de experiências oriundas de um grupo social que ocupa uma posição determinada nas estruturas sociais.

Os dados encontrados na pesquisa convergem com o estudo de Pereira et al. (2005) no qual a renda individual de grande percentual dos pacientes estudados não passava de um salário mínimo. A pouca escolaridade e a baixa renda são fatores de risco para o desenvolvimento da hanseníase, havendo comprometimento da qualidade de vida, sobretudo relacionado às relações sociais e aceitação da doença.

Para Bury (2011), ocupação e classe social estão intimamente relacionadas, embora sua relação na doença seja complexa. A importância da classe social reside na distribuição variável dos recursos na sociedade, assim como a habilidade de indivíduos de diferentes estratos sociais compensarem os efeitos da incapacidade e assim contrabalançar deficiências econômicas de outros tipos.

O sistema de reprodução social constitui as formas de vida das diferentes frações de classe social incluindo os padrões de consumo e trabalho, as atividades práticas da vida cotidiana, as formas organizativas ou de participação social e política e a cultura. As desigualdades nas condições de vida, decorrentes de diferenças substantivas nesse processo de reprodução social ocasionam reflexos nas situações de saúde, que são as iniquidades (BARATA, 2012).

A formação social e a estrutura de classes encontram-se na dimensão macrossocial, isto é, são determinantes para a inserção econômica e social dos indivíduos, inserção esta que vai condicionar em grande medida os padrões de consumo 
e as estratégias familiares cotidianas retratadas pelo nível socioeconômico. Os estilos de vida ou os comportamentos individuais são apenas as evidências mais imediatas de todo o processo de determinação-mediação, que ocorre entre as diferentes dimensõesdesde a formação social concreta existente em determinado período histórico e espaço geográfico, passando pela estrutura de classes, pelas estratégias das frações de classes e famílias até os comportamentos dos indivíduos (BARATA, 2012).

A hanseníase pode atingir um indivíduo inserido em qualquer grupo social, mas a incidência é maior nos segmentos mais empobrecidos da população, devido à presença de condições socioeconômicas desfavoráveis. Portanto, as condições precárias de vida e saúde, facilitam a contaminação e a propagação do bacilo de Hansen (LOPES E RANGEL, 2014).

A pobreza, por si só, é um fator determinante de hanseníase. A transferência de renda reduz não só a pobreza, mas também aspectos específicos da pobreza associados à hanseníase, tais como desigualdade, subnutrição e escassez de alimentos. Há uma evidência consistente de que programas de transferência de renda condicionadas aumentam as despesas com alimentos. O Programa Bolsa Família (PBF) aumentou o acesso e melhorou a qualidade e a diversidade dos alimentos (NERY ET AL., 2014)

"Eu vivo lá é de ajuda, a minha mãe me ajuda compra pão pra mim, porque eu não tenho de jeito nenhum. Aí eu recebo só essa bolsa família (...).” (Ália)

Programas de transferência de renda são um caminho para impulsionar a demanda e reduzir barreiras de acesso aos serviços de saúde da população pobre e extremamente pobre, particularmente na atenção básica. Assim, é necessária uma atenção básica resolutiva, compatível com as necessidades de saúde da população e que atenda as demandas exigidas pelos programas de transferência condicionada de renda. Com a expansão dos programas de transferência de renda e sua relevância para a saúde pública, é necessário acumular evidências de mecanismos e caminhos através dos quais a transferência de renda afete epidemiologicamente fatores relacionados à hanseníase e outras doenças da pobreza (NERY etal, 2014).

O perfil socioeconômico dos pacientes no estudo de Lopes e Rangel (2014) confirma a tendência, pois registra a presença de trabalho precarizado associado a baixos níveis de renda e de escolaridade; significativa presença de famílias extensas e baixo acesso a programas assistenciais. 
"Porque as meninas aqui no HUB, eu recebo uma cestinha! A gente tá vivendo com essa cestinha!" (Salma)

A relação entre o acesso aos serviços de saúde e a pobreza, que pode se tornar um círculo vicioso, está extensivamente descrito na literatura. A busca por tratamento de saúde tardia devido à pobreza aumenta o risco de lesões de pele e deficiências, enquanto os dados mostram que a hanseníase claramente tem uma influência negativa no status socioeconômico das famílias (PETERS ET AL, 2013).

\section{Atendimento e Diagnóstico}

As entrevistas mostraram que houve demora no diagnóstico ou tratamento incorreto em nove pacientes $(33,33 \%)$, o que mostra que ainda há dificuldade ou desconhecimento da doença. Estes pacientes relataram que fizeram várias consultas e exames, em postos de saúde públicos e consultórios privados, e tratamentos equivocados até chegar ao diagnóstico de hanseníase. Dentre os tratamentos equivocados, o mais comum foi achar que era micose nos pacientes que apresentaram como sintoma inicial manchas, rinite, quando o sintoma era sangramento nasal, leishmaniose, artrose e até cirrose.

\footnotetext{
"Foi muito exame. Eu fui no posto, fui no hospital, aí fiz exame particular e ninguém descobriu o que que era. As perna tinha inchado, aí os médico falava que era cirrose, mas eu nem bebo[risos] pra ser cirrose. Aí foi até que com uma amiga minha, ela faz tratamento aqui e conseguiu uma consulta aqui pra mim. Eu acho que eu fiquei uns 3 meses mais ou menos, tentando descobrir. De hospital em hospital e não... tava ruim, tava debilitado, que eu tava, nem andava direito, seco, seco, seco..." (Misael)
}

Batista (2014) também verificou que a maioria dos pacientes relata um percurso longo até o diagnóstico de hanseníase, dentre eles, relatos sobre anos de peregrinação por diversos médicos e diversos exames, tratamentos realizados supondo-se outras doenças, tais como problemas de coluna, micoses e lúpus. Para este autor, os relatos revelam que os médicos, em geral, possuem treinamento insuficiente e inadequado para a realização do diagnóstico em hanseníase.

No estudo de Peters et al. (2013), muitos médicos não identificaram imediatamente hanseníase, diagnosticando a hanseníase como sarna, alergia ao suor ou micose. Quando a doença não melhorava, os pacientes retornavam à clínica para descobrir que estavam com hanseníase. Da mesma forma, trabalhadores de saúde afirmaram que os pacientes subestimavam a severidade dos sintomas, pensando ser, por 
exemplo, um "buraco de verme", e, como resultado, demoravam a buscar atendimento.

"Olha, que eu me lembro... Eu me alembro assim: que eu... teve um dia que amanheceu o dia e aí, minha mãe não podia lavar pano, né, tinha problema. Aí, eu saí cinco horas da manhã pro rio pra lavar os pano, porque no poço tava quebrado. E aí, quando eu cheguei em casa, eu já cheguei toda empolada, né. Aquelas mancha vermelha. Aí, com o tempo, aí ficou ple... preta. Começou a ficar preta, roxa, aquelas mancha. Só nas... Mas só nas perna. Tinha só... Tinha só nas perna. E aí, eu fiquei caminhando pro médico lá. Passei dois anos caminhando pro médico lá e eu sem descobrir. Porque era só remédio pra micose, essas coisas. ” (Rebeca)

Resende et al. (2009), mostra que um dos principais fatores da alta prevalência foi demonstrado, onde a presença das formas MB refletiu a demora no diagnóstico da doença. Os autores inferem que a distribuição espacial das formas clínicas está diretamente relacionada com a desigualdade de acesso aos serviços de saúde e a falta de conhecimento da população. Também deve ser dada ênfase à forma indeterminada para o início do tratamento, pois o paciente apresenta poucos bacilos, não sendo fonte de transmissão. Assim, acredita-se que o diagnóstico da hanseníase está sendo realizado tardiamente, o que favorece um maior número de manifestações e lesões decorrentes da própria evolução da doença.

Sousa et al. (2013), encontraram, em estudo com pacientes que abandonaram o tratamento PQT, que a maioria era portadora da forma dimorfa e virchowiana e com classificação operacional MB, ou seja, as formas da hanseníase responsáveis pela ocorrência de incapacidades físicas, danos neurológicos e transmissão da doença, indicando ainda um sinal de que o diagnóstico ocorreu tardiamente, demonstrando um despreparo da equipe de saúde na identificação dos casos, colaborando, assim, para a manutenção da cadeia de transmissão da doença.

Resende et al. (2009) apontam que o diagnóstico tardio é consequência da carência de ações educativas, a nível comunitário, fazendo-se necessária a divulgação intensiva dos sinais e sintomas da doença por meio de seminários, cursos, treinamentos e mensagens nos meios de comunicação de massa, visando estimular a procura pelo serviço de saúde dos sintomáticos dermatológicos, favorecendo assim o diagnóstico precoce e o tratamento correto, fundamentais para o controle da endemia e para desestigmatização da doença.

Muitos pacientes entrevistados não deram importância aos sintomas:

"Era no rosto e no bumbum. Aí eu não liguei muito. Aí depois foi ficando vermelho, ficou tipo como se eu tivesse tomado sol, aí fica bem... aí ela[sogra] veio aqui, falou com ele, aí 
ele[médico] pediu pra ela me trazer. Aí ele chamou os médico tudinho eu fiquei com medo na hora. Aí eles pediram pra fazer o exame, fizeram o exame da orelha e constatou que eu estava com hanseníase. " (Salomé)

Assim como no estudo de Bury (2011) sobre artrite reumatoide, no qual, num primeiro momento, a debilitação era simplesmente considerada um incômodo. A única explicação buscada era do tipo proximal, isto é, o senso comum forneceu parcialmente a resposta.

"Uai, foi assim, eu vim aqui pra tratar de outra coisa, sabe, duma alergia que eu tô com ela. E aí eu tinha uma mancha, já tinha uns 5 anos que eu tava com essa mancha e eu mostrei pra médica, o dia que eu vim. Aí ela pegou e pediu uma biópsia, né, pediu pra fazer uma fisioterapia, eu fiz. Aí da outra vez que eu vim, no retorno, ela pediu pra mim fazer o tratamento." (Palmira)

Muitos pacientes demoram a procurar atendimento médico por medo de faltar no trabalho. Preferem ocultar sua doença para não serem demitidos ou aposentados precocemente. $\mathrm{O}$ aparecimento da doença traz dificuldades no trabalho, principalmente associadas à liberação mensal de suas atribuições para comparecer à Unidade Básica de Saúde (UBS), colocando em risco a continuidade no emprego (SOUSA et al, 2011).

\footnotetext{
"Aí teve um dias que...eu trabalho como garçonete...e aí eu...a bandeja caiu da minha mão assim do nada, assim sabe...caiu da minha mão....aí comecei...eu sentia que o meu pé tava...não tinha mais sensibilidade, assim, sabe. [...] Aí quando foi um dia assim, já comecei a ficar com uma febre, uma febre, não queria passar...uma febre, uma febre... 'gente, meu corpo tá muito estranho! ' [...] Mas eu não tava me sentindo bem, minha mão tava atrofiada, uma coisa assim muito estranha....aí eu peguei, me deitei debaixo do balcão, nunca fiz isso...tanto que eu tava ruim assim. Aí minha chefe me procurando no hotel inteiro... [risos]...e eu lá deitada. Aí a colega de trabalho falou assim: 'ela não tá bem, tá com a mão atrofiada, tá trabalhando...' . E eu comentei o meu pé, o peito tá batendo no chão, nunca senti essas coisa. Eu falei pra ela 'tá muito estranho'. Aí eu lá deitadinha debaixo do balcão, com tanta febre e eu não queria deixar ela na mão, sabe, assim. [...] Aí minha chefe pegou me chamou lá no escritório, aí ela: [...] 'eu tô notando que tem umas coisa estranha...' aí eu mostrei minha mão pra ela, ela ficou horrorizada. Que o dedo não tava mais conseguindo abrir. Eu falei assim: 'não, doutora, é que eu gosto muito do meu trabalho. Eu achava que ia dar conta...achava que era uma coisa assim nesse sentido, não sei o quê...' ela assim: 'cê vai agora no médico. [...] Ninguém vai te substituir....sua vaga aqui ninguém vai tomar'." (Betsabé)
}

No estudo de Bury (2011), uma das pacientes relatou que sentia que seus colegas de trabalho não eram muito compreensivos e que ela não poderia pedir consideração especial e estava sob pressão para acompanhar o ritmo de trabalho e constantemente com medo de perdê-lo. Como aponta Lael:

"E lá no serviço, eles não tem dó, não! Se você levar atestado de comparecimento, eles ainda metem a falta em você! Porque pra eles, como é Goiás, Goiás é terra sem lei e não tão nem aí, não. Eles não tem dó, não. Não. Não. Assim, porque os donos, não. Os donos não estão nem aí, não. Mas as pessoa que são de dentro, que são pago pra fazer, eles não tão nem aí, não. Pra eles tanto faz! Eles acham que eles nunca vão adoecer; uma hora a família. Agora, se algum parente deles adoecer, aí eles passam dois, três dias, cinco. Recebe tudo do mesmo jeito. ”(Lael) 
A perda do emprego, seja por demissão, seja por dificuldades físicas para seguir trabalhando, gera um medo grande nos pacientes: o medo de não conseguir sustentar sua família (EIDT,2000).

\footnotetext{
"Mas como foi agora eu imaginei que tinha que vim porque lá eu...o problema da minha saúde tá cada dia mais difícil. Eu não posso... até no ônibus quando eu vim, minha mão é dormente ó, minhas perna dói, meus pé é dormente, eu não posso nem pisar no chão, eu não consigo trabalhar, de jeito nenhum..." (Ália)
}

A grande maioria dos pacientes informou que se sente bem atendido, nenhum dos pacientes reclamou do atendimento em si; o que também contém o viés de a entrevista estar sendo feita no local de atendimento, falta de intimidade com a entrevistadora ou talvez medo de perder o atendimento. Essa percepção dos pacientes sobre o atendimento que receberam da equipe de saúde pode ser interpretada como reflexo da satisfação que tiveram em relação à equipe de saúde que lhes atendeu ou algum atendimento específico.

Quando questionados como avaliavam o atendimento, foi possível perceber contradições na fala de alguns pacientes, que consideraram o atendimento bom, pois, afinal, estão sendo atendidos. Estas contradições podem ser explicadas pelo fato das entrevistas terem sido feitas no próprio local de atendimento.

“Tá bom, né. Tem do que reclamar não, pelo menos é atendido.” (Misael)

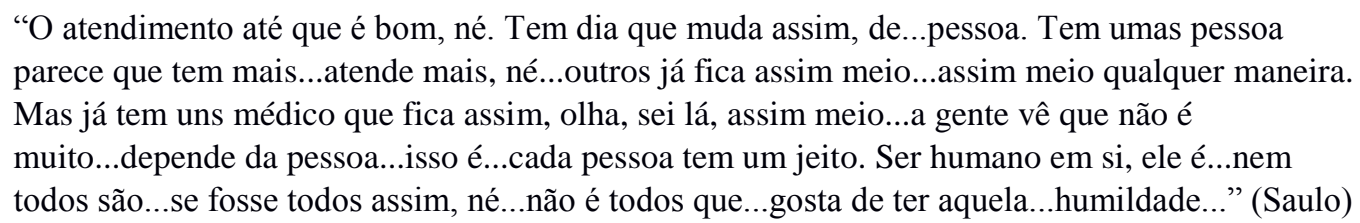

Pereira et al. (2005) associam o baixo nível de escolaridade e de condições socioeconômicas dos pacientes ao baixo padrão de percepção dos seus direitos, e ao pequeno nível de exigência destes direitos. No debate acerca da hanseníase e sua determinação social, à presença das desigualdades sociais se agrega o acesso aos serviços públicos, pois este poderá reproduzir as desigualdades ou minimizá-las, diante de sua efetivação ou não. Por isso, o acesso público a uma escola de qualidade, aos serviços de saúde e de assistência social e a inserção no mercado de trabalho são essenciais para o desenvolvimento do combate a doença (LOPES E RANGEL, 2014)

Para 10 pacientes do estudo (37\%), o diagnóstico foi rápido, isto porque destes, 
sete $(25,93 \%)$ conseguiram consulta diretamente no HUB, com ajuda de amigos ou familiares que ali trabalham, como contam Salomé e Zora:

\begin{abstract}
"É...a minha sogra trabalha aqui, na limpeza e ela me encaminhou pro doutor. Aí com as manchinhas eu não me importei, achei que era uma micose...” (Salomé)

"E tinha uma amiga nossa que trabalhava aqui na época. Aí ela conseguiu uma consulta pra mim aqui numa quarta-feira." (Zora)
\end{abstract}

Como mostrou o estudo de Montagner (2011), muitos acreditam que o atendimento obtido junto ao SUS é "de favor" e não de direito, então para esses pacientes, esperar e não conseguir seria natural já que é de graça. Para esses pacientes, contestar as dificuldades encontradas em conseguir atendimentos e exames seria inútil, assim, com a ajuda de conhecidos dentro do hospital, conseguem acessar o serviço rapidamente.

Estes fatos apontam problemas na acessibilidade organizacional do sistema, que são os problemas de acesso aos serviços de saúde devido a obstáculos originados pela forma em que a acessibilidade é organizada. Tais obstáculos podem estar tanto na entrada quanto no interior dos serviços de saúde, referindo-se assim a demora para se conseguir uma consulta, a espera pelo atendimento, para ser atendido pelo médico, para fazer exames, para receber os resultados e medicação. Assim sendo, a questão da demora simboliza bem o problema da acessibilidade organizacional, levando-se em conta ainda a continuidade de tal assistência (FEKETE,1997; SILVEIRA, 2009).

\footnotetext{
"No começo, a gente não sabia porque a gente é do... a gente morava no interior do Piauí; e aí, a gente veio pra cá... E fui... viajei de férias, e quando eu voltei, já voltei com... com os carocinho nas mãos. Só que, também, a gente não se preocupou em procurar o médico, né. Porque aqui é tudo mais difícil! Aqui, se você não tiver uma pessoa que... que lhe ajude pra você conseguir as coisas, você não consegue. Aí, como a gente... eu já trabalha no mercado, e tem a gente... tem os amigo lá, e pegou e arrumou, conversou com a pessoa que trabalha aqui, ele foi, me encaminhou e... Como o médico lá do Gama me deu o encaminhamento, eu vim aqui no mesmo dia... é... no dia seguinte, e eles me barraram, que não tinha médico pra atender. Hoje em dia, se você não tem uma pessoa de confiança que você possa contar com ele..." (Lael)
}

No estudo de Peters et al.(2013), realizado na Indonésia, muitos participantes afetados pela hanseníase faziam tratamento nos centros comunitários de saúde e alguns relataram que enfrentaram barreiras para receberem atendimento.

\title{
Relação com o corpo
}


Sousa et al. (2011), relatam em seu estudo que os pacientes, ao serem questionados sobre o diagnóstico da hanseníase, procuraram o serviço de saúde devido ao aparecimento de manchas com dormência no corpo, dor nas articulações, mãos e pés e astenia de membros e queimação no corpo em igual proporção. Alguns pacientes relacionaram seus sinais e sintomas à hanseníase demonstrando possuir algum conhecimento a respeito dos sinais e sintomas característicos da doença, o que pode estar relacionado às campanhas de divulgação na mídia.

"E aí, quando foi um dia - eu não sei se no jornal ou na televisão - aí falou na... na... na propaganda, na doença, né... na televisão. E aí, eu fui pro... na... pro médico. E aí, eu cheguei lá e falei pra ele: 'Doutor, essas mancha nas minhas perna não é a hansaníase que eu peguei no jornal? Porque quando a gente tá com as mancha que não sente contato. É... é ela! É essa doença!' Aí, ele disse: 'É, pode ser. Vamos fazer o teste pra gente ver.' Aí fizeram o teste do... da agulha e do quente e do frio, e aí foi que ele veio e passou um remédio pra mim tomar." (Rebeca)

Para compreender melhor os conflitos existenciais, vivenciados pelos entrevistados, deve-se refletir sobre o significado do corpo na vida das pessoas e como articular e harmonizar, na prática médica, as diferentes percepções de corpo que cada paciente traz ao buscar atendimento (EIDT, 2000).

\footnotetext{
"Começou em agosto, do pé! Foi! Ainda não tem nem ano! Aí do... do... do pé subiu pra... pra cá pra... pro rosto, né?!... meu rosto inchava! Aí saiu uns negócio aqui: uma... Minha cara parecia um ralo! Até esse mês saiu, porque minha cara ficou dessa grossura! Isso aqui ficou inchado! Eu pensava que eu tava com caxumba." (Safira)
}

Para Montagner (2011), as concepções de saúde-doença passam a ser relacionadas com as construções socioculturais, ou seja, o corpo começa a ser analisado como além de biológico, como social. Aliás, um corpo que recebe muito mais influência social do que biológica, como atestam inúmeros estudos. São muitas as questões que envolvem os temas gênero, sexualidade e saúde física, tanto de homens como de mulheres, relacionando-os às condições materiais de existência, aos fatores demográficos e às diferenças no cuidado e tratamento das diferentes camadas sociais.

Comumente, o ideal corporal de uma pessoa se ajusta aos padrões culturais prevalecentes do que seja ou não uma aparência agradável, visto que as pessoas reagem não apenas ao que dizemos e fazemos, mas também a nossa aparência (EIDT, 2000).

"Primeiramente, eu passei mais de um ano com essa doença sem eu saber, lá no Maranhão! Sem saber! Eu vim saber por que o meu rosto já tava cheio de manchinha preta... [...] Aí nos postos de lá, o médico passava era umas pomada da... chegou a passar uns comprimido, porque eles, na hora que olhava assim, achava que era um tipo de micose, né. Alguma coceira na... na pele. Aí me passou um medicamento, e uma... e umas pomadinha pra mim passar na mancha. Eu passava 
e não... não... não sumia nada e ficava do mesmo jeito. Só que eu não sentia nada. Nada! Nada! Nada! Nada! Eu me sentia normal. Só que o que tava me incomodando é aquelas mancha que tava no meu rosto e eu tava achando muito feia, e no meu bucho. Por isso que eu ia nos postos lá e não... não acusava nada. Acusava que o médico achava... Só que ele não fazia exame nenhum. [...]" (Rebeca)

A identidade da pessoa, em função da enfermidade, será alterada em função de suas dificuldades no desempenho profissional e social, pois a estrutura da vida diária deverá ser revista, reestruturada e planejada de acordo com a nova realidade. Nessa reestruturação novas atitudes e comportamentos também terão como base os fatores psicológicos (como por exemplo, a autoestima) e os fatores sociais (a reestruturação da rede social) (MONTAGNER, 2011).

“Olha! Eu fiquei muito desorientada, né. Antes... E depois, não. Aí controlei. A família continua com as ignorância, né. No caso, a vida pra mim em casa é muito difícil. Muito, do tanto que você pensar! Mas, toca a vida pra frente! Não... Não deixo me cair no fundo do poço mais, não! [risos] É. Essa família minha tem preconceito ainda. A gente na conversa, assim, e eles já falam. Assim..." (Lia)

Richardson et al. apud Montagner e Montagner (2011) consideram que a ruptura biográfica representa uma descontinuidade na vida do indivíduo e na sua interação social, provocando, por um lado, mudanças no seu comportamento, e, por outro, respostas para uma reconstrução do ritmo de vida. A maneira como as pessoas lidam com a enfermidade inscreve-se também no modo de vida de seu grupo social e nas suas condições de vida.

\footnotetext{
"Não...até que eu faço assim...mas é...fica mais dificuldade, né... o que era né...sempre a gente...não é como a gente era, né. É uma dificuldade é... tem serviço muitas vez cê não... não faz como faz isso, principalmente tem vez, vou fazer algum servicinho, fica meu corpo todo doído, as mão, meus pé...assim, quando tá mexendo alguma coisa, né. O corpo todo doído, tem dia assim, as mão...as perna...assim, às vez de ficar andando...dá dor nas perna assim...tem dia...no corpo assim...qual o problema assim...da...mão. Tem que maneirar, pior que é, tem que ir devagar...é...tem que maneirar. Não adianta querer forçar que depois fica pior, né...pode até ficar deitado... (Saulo)
}

De acordo com Le Breton (2011), o primeiro constituinte da aparência relacionase com as modalidades simbólicas de organização sob a égide do pertencimento sociocultural do indivíduo. Elas seriam provisórias e amplamente dependentes dos efeitos da moda. Por outro lado, o segundo constituinte diz respeito ao aspecto físico do indivíduo sobre o qual dispõe de pequena margem de manobra, como altura, cor da pele. A aparência corporal corresponde à forma do indivíduo se apresentar socialmente e de se representar cotidianamente. Engloba a maneira de se vestir, de se pentear, de tocar o rosto, de cuidar do corpo e que muda conforme as circunstâncias e de acordo 
como o estilo da presença do indivíduo (BATISTA, 2014).

Para Montagner (2011), a doença crônica não afeta apenas a pessoa que a possui, mas também sua família, sua rede de amigos, sua relação profissional e vida religiosa, inseridas em tantos grupos e instituições.

\begin{abstract}
"Começou com a dormência no pé. Num dia, eu dormi boazinha. E no dia seguinte, quando eu acordei, esse pé tava dormente que eu não sentia mais ele. Aí quando eu fui no médico lá, que um amigo da gente pagou a consulta pra gente, que a gente foi no dermatologista lá no Valparaíso, foi que ele falou assim: 'Olha! Você já tá mais ou menos com uns... uns dez anos com essa doença no corpo!' E eu disse: ‘E só agora que ela veio se manifestar? ' Porque dizem que ela é silenciosa, né. E eu disse: 'E só agora que ela foi se manifestar? ' E ele disse: 'É.' E eu disse: 'Meu Deus!' E sempre aparecia, assim, um... uns... uns caroço, umas mancha, mas eu nunca liguei pra aquilo. Eu achei que era uma coisa passageira, né. Aí quando ele foi lá que apareceu um... esse caroço aqui, aí é que ele tirou um pedacinho aqui, mandou fazer a biópsia e foi aí... foi que... que deu que eu tava com a hanseníase. Tinha alguma manchinha e... e... e eu fiquei desconfiada quando o meu... o pé começou a ficar dormente - que eu não sentia mais o pé. Entendeu? Ele começou a ficar dormente; começou a ficar, assim, grosso, inchado aqui - desse lado aqui - e tudo... Aí foi quando... quando ele fez o... a biópsia lá, foi que deu. Porque ele tava... Até então, ele pensava que era... que era câncer, essas coisas. E aí, quando veio o resultado, que ele viu que não era... Aí, ele ficou até mais aliviado, né. E a gente também, né. " (Lídia)
\end{abstract}

O diagnóstico provoca um impacto emocional intenso e negativo, deixando transparecer sofrimento e incertezas influenciados pela trajetória histórica contínua da hanseníase, carregada de estigma (EIDT,2000), conforma relata Betsabé:

"Por exemplo, eu fiquei em depressão dois ano depois da doença. Porque eu cheguei me vi na minha casa. Meu deus, eu gosto da minha casa muito limpa, eu sou muito limpa com minhas coisa. Aí então você imagina dois filho pequeno, você doente, não poder contar com ninguém, né...enfim...nossa...entrei em depressão. E depois eu vim aqui no médico...eu só chorava...vinha na consulta, só chorava, porque era remédio, era não sei o que...nunca tinha uma resposta boa, assim, né. E chorava.” (Betsabé)

Para Bury (2011), a ruptura da amizade e do envolvimento com a comunidade é causada não apenas por limitações funcionais (por exemplo, restrições de mobilidade), mas também pelo constrangimento que tais incapacidades criam. Assim, as deficiências do isolamento social e da dependência que fluem a partir dessas rupturas no intercurso social não se originam simplesmente da habilidade ou inabilidade de realizar tarefas e atividades. Os indivíduos começam a restringir seu território a locais familiares onde há pouca probabilidade de serem expostos aos olhares e às perguntas de conhecidos e estranhos. Alguns desejam se isolar por sofrerem preconceito ou pelo medo de sofrerem (MONTAGNER, 2011).

"Não. Não. Mudou só... só entre eu mesmo. Porque depois que eu voltei a tomar de novo esse mesmo medicamento... Porque quando escurece a pele da gente, né... a pele da gente, eu saí do emprego que eu tava, que eu ia todo dia, todo dia, todo dia... Eu que quis sair, né... devido... Eu 
fico muito incomodada porque a gente anda na rua e o povo fica procurando por que que eu tô assim. 'Ah! Tá muito pretinha! Tá muito moreninha!' Então... Fica fazendo muitas procura, né. Isso me incomoda...Devido ao meu rosto torrado! Voltar de novo... Ficar preta. Eu não gosto. Fiquei mais isolada em casa. Tô trabalhando também só três vezes na semana. Saí desse e tô ni outro. Só três vezes na semana. Evito o máximo possível que eu puder, assim, de sair. Porque eu acho que me incomoda muito. Ah! Ah! Os outros tá me procurando. Só que eles não sabem o que que eu tenho, né. Eu não falo muito... Pra ninguém, assim. A minha doença, assim. Pra ninguém eu não falo não, a não ser meus parente mesmo que sabe. Pra gente, assim, eu não ando falando muito, não. E porque procura demais e eu não gosto. Já procura demais é da minha culpa, porque eu sou mais clara. Sou bastante clarinha. Aí quando me vê assim, aí fica me procurando: 'O que que eu tenho? Por que é que eu tô assim, com a pele diferente?' E eu não gosto. Por isso que eu evito. É.” (Raquel)

Frente ao adoecimento, os pacientes constroem uma teia de significados, constituídas a partir de seus grupos de pertencimento, o que permite atribuir sentido à própria doença e a organizar suas ações e práticas. Assim, problematizar a hanseníase, tendo como base as pessoas que passam por essa experiência de adoecimento, pode contribuir para modificar as práticas educativas em saúde, não pela imposição de um saber técnico científico detido pelo profissional de saúde, mas pela legitimação dos saberes e dos significados que os pacientes possuem da própria doença e do adoecer (BATISTA, 2014).

\footnotetext{
“As pessoas tão muito ruins...elas não te visita mais por você, pelo que você tem...entendeu, minha filha? Se você tem uma coisa boa elas tão lá, se você não tem nada, você não tem mais ninguém na sua vida. Começa por parente, por amigo. Eu não tenho amigo, minha filha... não tenho amigo. Meu amigo é meus filho, meu marido e deus, sabe. Se chegar alguém na minha casa trato bem? Trato bem! Mas não significa que são meus amigo. E eu escolho quem entra na minha casa, não é todas as pessoas. " (Betsabé)
}

As transformações ocorridas no corpo provocam mudanças tanto na vida cotidiana das pessoas, tais como dificuldade em trabalhar, passear, como também nas suas relações sociais, como por exemplo, a perda de amigos que temem "pegar" a doença ou a perda do emprego (MONTAGNER, 2011).

\footnotetext{
"Mas assim, ó, como eu sou casada eu convivo muito com a família do meu marido. Então, de uma certa forma eu sofri muito. Muitos se afastaram. E se ferraram, porque eu continuo linda. [risos] Aí hoje quer chegar, eu não quero. Porque quando a gente mais precisa, o povo se afasta...distancia. Eles achavam que ia pegar." (Salomé)
}

A hanseníase gerou cicatrizes profundas nos entrevistados, pois o estigma permaneceu não somente no corpo, mas também na mente e no imaginário destas pessoas, cujas vidas sofreram grandes transformações devido às perdas que foram se efetivando ao longo dos anos. As transformações corporais, a rejeição e o abandono da família e dos amigos, a perda do emprego e da saúde, decorrentes da ameaça constante 
de reações, foram situações advindas da doença e que integraram o cotidiano de cada entrevistado (BATISTA, 2014).

\begin{abstract}
"É. Eu tenho uma irmã. Eu não falo com ela. Não falo com ela. Não vou na casa dela. Ela tem medo de pegar na... nas duas filha dela. Eu acho que isso aí não tem nada a ver, de... Se eu tratei, não vai passar pra ninguém, tá. As sequela tá em mim. Não tá prejudicando ninguém, não. Lá em casa ninguém tem mais sem ser eu. Ninguém deu. Meu esposo deu, mas a gente já tava vinte e cinco anos separado. Porque a gente... Casei com ele naquele padre, sabe. Naquele homão... Aí trocou eu por outra de 20, aí... Daí morreu pior do que eu. Morreu com toberculose e hansenía. Mas eu não sabia que ele tinha toberculose. Eram os remédios, não deu certo com a toberculose, e os remédios pra hansenía. Aí ele morreu." (Salma)
\end{abstract}

A carga negativa da doença também se expressou em sentimentos de tristeza e desamparo, verbalizados e objetivados também por meio do silêncio e do choro no momento da entrevista. Neste cenário de sofrimento, estavam presentes sentimentos de impotência diante de uma doença que traz consigo sequelas que vão além das incapacidades e deformidades físicas (BATISTA, 2014).

\footnotetext{
"Tem que tipo se adaptar. Quando comecei, eu comecei num trabalho...só que aí, já tive...eu tive que sair. Quando comecei nesse era fichado [com carteira de trabalho assinada], né. Aí não já dava, devido... acordava atrasado, aí era exame, ir consulta, pegar remédio, então atrapalhou muito, aí eu tive que sair...do trabalho, né, porque não tava dando certo, muito atestado." (Misael)
}

O corpo assume para essa classe um aspecto de utilidade mesmo porque suas atividades diárias, sejam profissionais ou domésticas, estão muito mais ligadas à força física. O bom funcionamento do corpo reflete na sua capacidade de trabalho e de não depender de outras pessoas. Logo, o corpo representa a possibilidade de trabalho, de sustento e cuidado para a família. Assim, o corpo saudável é aquele que aguenta todo o cotidiano sem apresentar dores ou incapacitações. O cuidado com a saúde assume a forma de manter o corpo em funcionamento. Ainda, é por meio de como o corpo se apresenta que há o reconhecimento e a aceitação social e por meio dele se demonstra a capacidade pessoal em cumprir os papéis sociais (BOLTANSKI, 1989; MONTAGNER, 2011).Segundo Bourdieu (1998), o corpo tem em si impresso os princípios da divisão social, o que justifica a distinção de classe.

"Não é porque eu queira me encostar, eu sempre trabalhei...eu não tenho mais condição. Ela [a filha] vai pro serviço dela, eu fico o dia todinho em casa. Assim, se eu passo uns dois dias melhora, se eu vou varrer uma casa eu passo mal, se eu vou fazer uma coisa eu me sinto mal, aí eu me sinto mal nem a sola dos pés, é o corpo todo...é uma coisa que eu sinto tão forte em mim. Aí começa nos meus olhos, eu tenho uma dor na minha cabeça, assim... ardendo, não sei se é...depressão... e pra mim não tá nessa depressão, eu me seguro, como todo mundo se segura em jesus. E justamente, ter saído de casa, tá aqui, nessa distância, mas mesmo tando em casa eu não consigo fazer nada. [...] ]a patroa dela[filha] também ajuda muito. E tudo que ela faz eu fico com 
pena. Tudo que ela faz, divide comigo e minha mãe. E é assim... senão não sei nem como é que eu tava...com depressão. Acho que é as dor que eu sinto assim na minha cabeça... (Ália)"

O corpo assume papel central no processo de relação interpessoal, pois serve como meio de comunicação. O paciente percebe seu corpo mutilado pela doença e, por isto, com frequência, isola-se ou é isolado do seu ambiente familiar, social e profissional. Outras vezes, mesmo que não demonstre nenhum sinal da doença, desde o momento em que o meio social no qual vive descobre sobre a hanseníase, ele passa a ser marginalizado e segregado (EIDT, 2000).

"E muito[preconceito]! O povo! Eu nem falo, quase, isso ou aquilo. Porque eu faço tratamento de lúpus também. Porque eu tenho lúpus. Aí junta os dois, e aí, enterra mesmo! "(Joabe)

No estudo de Peters et al. (2013), muitos participantes não estavam mais fisicamente aptos para fazer o trabalho que costumavam executar. Alguns foram despedidos, como um faxineiro de um hospital, enquanto outros se resignaram como sugerido pelos familiares. Agricultores também tiveram problemas porque ficavam parados na mesma água durante o plantio de arroz e as pessoas ficavam com medo de serem infectadas. A situação econômica dos indivíduos afetados e suas famílias piora e o status socioeconômico do chefe de família influencia outras atividades como, por exemplo, educação.

As atividades profissionais passam por uma reavaliação, pois elas não poderão mais fazer esforços e essa limitação vai impactar negativamente sua identidade. Para a maioria o trabalho é visto como um fator positivo em suas vidas, e ainda mais, quando elas são chefes de família a falta do dinheiro que elas antes provinham, significa sérios problemas (MONTAGNER, 2011).

\footnotetext{
"No começo, era muito difícil. Eu tinha que ficar mais em casa do que trabalhando. Nossa! Dói! Até hoje ainda dói. Só que não dói igual antigamente. Hoje é leve. Mas, antigamente, eu não me tenho... época que eram os meus vizinhos que me pegavam dentro de casa, botava no carro pro hospital. Porque é muita dor. Só quem passa é que sabe. Quem nunca passou, não... Peço a Deus que ninguém passe um dia, porque é muito dolorido.” (Lael)

É grande o impacto que as pessoas sofrem por não conseguir realizar suas tarefas cotidianas. Em especial, quando essas tarefas estão ligadas à sua profissão, ou aos meios econômicos que escolheram, ou que lhes foi possível para prover suas necessidades básicas, desde a alimentação até o lazer (MONTAGNER, 2011).
}

As sequelas, deformidades físicas e estados reacionais, são dificuldades significativas enfrentadas nas relações e na execução de atividades do cotidiano. A 
realização de tarefas simples acaba afetada quando os doentes perdem a sensibilidade de algum membro e simples atos da vida diária acabam prejudicados quando atingidos pelas sequelas físicas da hanseníase (EIDT, 2000).

"Tô te falando, a consulta que eu vinha, passada...eu perdi o chinelo. Porque eu tava tentando usar o chinelo, tem dez ano que eu não consigo usar um chinelo. Aí eu falei assim, minha filha, bota um elasticozinho atrás, pra tentar usar o chinelo...aí ela botou, não sei como foi, o elástico caiu, não sei que que aconteceu, mas eu cheguei em casa sem o chinelo, eu não vi nem onde o chinelo foi parar, juro pra você, não sei nem onde o chinelo foi parar. Pra você ter uma ideia." (Betsabé)

A hanseníase faz com que o paciente viva com manchas, cicatrizes, pele escurecida, perda de sensibilidade e deformidade física. Além disso, muitos pacientes apresentam reações da hanseníase após estarem curados, causando dor, câimbras e/ou parestesia, fazendo com que continuem a sentirem-se doentes. Todos estes impactos físicos mudam suas vidas e também influenciam sua situação emocional, social e econômica. Tristeza, frustração, perda de confiança, desvalorização da própria capacidade, estresse e desesperança são algumas das emoções descritas devido à hanseníase (PETERS ET AL, 2013).

\footnotetext{
"Depois que minha filha nasceu...porque meus pais, a gente sempre morou na roça, aí não tinha aquela coisa, aquele contato que a gente queria ter. Aí minha filha muito elétrica, a gente quer acompanhar ela, mas tem hora que...é impossível, né...[risos]” (Elias)
}

Quando o paciente percebe que não mais consegue realizar suas atividades diárias, quer seja no cuidado com a casa e com os filhos, quer seja com o trabalho, inicia um processo que chamamos de reelaboração de sua vida. É o momento no qual ele vai avaliar a duração dessa situação, e, de acordo com esse tempo começará a tomar novas decisões (MONTAGNER, 2011).

“[...] Aí esse dia que eu vi meus filho lá jogadinho assim. Aí eu falei assim 'não, vou sair dessa depressão, isso não me pertence mais. A partir de hoje'." (Betsabé)

Ficaram evidentes questões como o abalo e a perda da autoestima, as discriminações sofridas e as dificuldades encontradas em realizar tarefas domésticas e profissionais com as sequelas físicas instaladas (EIDT, 2000).

As relações sociais sobre o trabalho vêm acompanhadas de duas dimensões principais: um conteúdo moral e uma dimensão de necessidade, em que o trabalho é tomado como gerador das possibilidades de sobrevivência. A capacidade de trabalhar 
significa autorrealização e o não trabalhar afeta de forma negativa a qualidade de vida. Pode-se pensar que a exclusão do mundo do trabalho aparece como uma morte social, pois o indivíduo se sente incapacitado para o trabalho e perigoso ao convívio com a sociedade em decorrência do possível risco de contaminação, mas, sobretudo pelo estigma que a doença carrega (BATISTA, 2014).

\footnotetext{
"Que é difícil, né! Você trabalha, toda ativa...depois você tá toda atrofiada lá...não é fácil! Eu passei já uma barra assim...necessidade mesmo, que os remédio...mas eu nunca desisti, nem vou desistir... nunca desisti...eu ainda creio que eu ainda vou ficar bem. Eu quero dançar, sabe. Meu sonho é dançar. Mas eu vou conseguir! ” (Betsabé)
}

O paciente precisará desenvolver meios de ajustar sua vida e a de seus familiares, mudanças deverão acontecer desde o tempo que terão de destinar às consultas médicas, aos tratamentos e aos cuidados de si e tudo isso requer novos comportamentos, em geral, ao nível prático (MONTAGNER, 2011).

\footnotetext{
"Venho... é... uma vez por mês. Tem... Já teve vez de eu vim aqui até duas, três vezes por mês! Porque, às vezes, eles pedem o negócio de inxame, né. Tem que fazer, né. Nossa Senhora! Eu tenho gastado, viu. Eu tenho sofrido. Igual eu falo pra enfermeira: 'eu só venho de carro fretado. Tiro da boca pra poder vir aqui. Pra cumprir com a obrigação aqui, que eu preciso da saúde.' Então, é nessa luta! ” (Bartolomeu)
}

Além do notável processo de exclusão, observam-se ainda comportamentos de auto exclusão, que podem ser percebidas por meio da adequação à condição de inferioridade atribuída aos pacientes, tais como deixar de sair de casa e deixar de frequentar lugares anteriormente frequentados. O estigma está diretamente relacionado à imagem corporal, de modo que as sequelas deixadas nos corpos dos entrevistados contribuíram para o fortalecimento da imagem de corpo sequelado. A partir do momento em que a autoestima é abalada, lidar com uma doença crônica e incapacitante como a hanseníase torna-se ainda mais difícil (BATISTA, 2014).

"Eu tenho de mim mesmo, sabe...que eu tenho!" (Jesabel, sobre preconceito)

\section{Medicação}

Em relação à cura, compartilha-se do pensamento de Canguilhem (2009) o qual afirma que a ideia de cura deve remeter a algo inexistente anteriormente à experiência da doença, um novo estado fisiológico, porque nenhuma cura é uma volta à inocência biológica. Curar é criar para si novas formas de vida, às vezes superiores às antigas, há uma irreversibilidade da normatividade biológica. 


\begin{abstract}
"Ainda sinto muitas dores, que meus nervos, eles são todos fracos. Porque a verdade é o que eu penso... a verdade é quem: tem esse problema, toma medicamento, dá uma empaleada, como diz a minha mãe, mas... pra falar assim: 'ah, que você sarou, que você não...' Acho que não sara não. Para pra ela não aumentar mais, mas aquilo que ela deixou de sequela no meus nervo, a fraqueza, ela...num vai voltar. A tendência é aumentar, porque eu vou ficando velha, a tendência é ficar fraca." (Ester)
\end{abstract}

A dapsona (DDS) firmou-se como a principal droga anti-hansênica e estratégica para o controle da doença na década de 1950. Posteriormente, a partir de 1962, a clofazimina (CFZ) e a rifampicina (RMP) começaram a ser utilizadas no tratamento da hanseníase. A OMS, em 1981, introduziu a quimioterapia combinada com três drogas, conhecida como poliquimioterapia (PQT/OMS), que consiste no uso das três drogas consideradas as melhores: DDS + CFZ + RMP. A PQT/OMS começou a ser implementada no Brasil em 1986 e, em 1991, foi adotada oficialmente pelo Ministério da Saúde (MS), sendo o tratamento poliquimioterápico recomendado para todos os casos de hanseníase. Todavia, sua administração chegou a ser questionada pelos centros de saúde espalhados pelo país, em função dos muitos casos de efeitos adversos. Ao implementar a PQT, questões relevantes como os prejuízos causados pelos efeitos adversos às drogas, assim como o manejo desses efeitos não foram levados em consideração, sendo que tais questões podem contribuir efetivamente para o afastamento do paciente e, ainda, levar à adoção de esquemas monoterápicos pelas equipes de saúde, que aumentam a probabilidade de resistência medicamentosa (GOULART et al, 2002).

"Mas esse... esses dois, que eram vermelho, eu passava dois, três dias fazendo xixi vermelho! Aí parecia que eu tinha engolido um dragão! Ficava aquele fogo por dentro! Um fogo! ” (Olímpia)

A clofazimina tem como um dos efeitos adversos a coloração avermelhada na pele e urina. $\mathrm{O}$ escurecimento da pele inicia por volta do terceiro mês de tratamento e atinge sua máxima intensidade até o final do primeiro ano. Porém, após a interrupção do tratamento, a coloração começa a diminuir em seis meses, e a pele volta à sua cor normal ao final de um ano após a suspensão da PQT (FERREIRA, 2013).

É... Um depois que eu tomasse o café...Eu tomava um comprimido branquinho. E a noite, depois da janta, eu tomava um escuro, que esse que... escuro, é que... é... que escurece a pele, né...” (Lídia)

Os pacientes relataram que a medicação escurece a pele, causa tonturas e malestar, assim como nos estudos de Nunes et al. (2011) e de Batista (2014), que encontraram relatos semelhantes em relação aos efeitos indesejáveis do tratamento 
medicamentoso, como por exemplo, o escurecimento da pele.

"[tomar o remédio] De novo! Já imaginou, ficar pretinha de novo! (Salomé) "

Peters et al. (2013) descrevem a importância do escurecimento da pele, um efeito colateral da clofazimina, precisa ser destacado, pois algumas vezes deixou o paciente em situações desconfortáveis quando questionado sobre sua condição. Isto influenciou seu conceito sobre sua própria beleza e limpeza e a dos outros. o que mais aparece em termos de características é o escurecimento da pele como efeito colateral da PQT. Os pacientes afirmam que algumas vezes é a pele escura e não a hanseníase que os faz se sentir inferiores. Assim, é a pele escura que desencadeia perguntas de amigos e vizinhos fazendo com que os pacientes sintam-se desconfortáveis. Um paciente mentiu na entrevista de emprego dizendo que sua pele estava mais escura porque ele gostava de soltar pipa. Uma observação importante a fazer é que na Indonésia uma pele mais clara é percebida como mais bonita ou mais "limpa" que uma pele mais escura, ilustrada pela resposta de uma mãe cujo filho tem hanseníase: "eu fiquei surpresa porque ele ficou com a pele tão escura. Ele era tão claro antes, mas ele ficou escuro... ele era tão escuro, muito, muito escuro.".

\footnotetext{
"Seis meses tomando esse remédio, que a gente saía pirada! Perdendo... Não tava no ônibus certo, a gente descia na pista. $\mathrm{O}$ guardinha parava os carros todinho e atravessava a gente naquela pista, e a gente tava no ônibus certo, e a gente descia no sol quente, calçada, e o sapato machucando o pé da gente... E eu rastando a outra. Passando aquela dificuldade porque a gente ficava pirada com esse tanto de remedi. " (Salma)
}

Batista (2014) verificou que a ameaça de recidiva e o tratamento, muitas vezes contínuo, atribuem à doença um caráter de incurabilidade, sendo assim, nenhum paciente sai igual depois de um diagnóstico de hanseníase, pois a doença se faz presente diariamente, seja pelas sequelas físicas, pelos exames de controle, pela ameaça ou a reativação das reações hansênicas. Este comportamento pode ser verificado, com frequência, na maioria dos pacientes, os quais se deparam com sentimentos de inquietude e ansiedade frente à possibilidade de uma reação hansênica. $\mathrm{O}$ possível retorno das manifestações clínicas após a cura é aterrorizante. E aí se instala uma discrepância: existe o discurso da equipe de saúde de que a hanseníase tem cura, no entanto, os pacientes convivem diariamente com a possibilidade de reativação dos bacilos.

"Eles me deram um ano. Aí quando foi um ano, encerrou um ano, aí que foi em 2007, eles encerraram e passaram um medicamento pra mim tomar, que era prednisona. Aí, dessa 
prednisona, vinha isso aí... inchando, inchando, inchando, inchando, inchando... Isso já tava com um bocado de tempo. Eu acho que já "tava" com um ano, já, que eu tava tomando ele, esse prednisona. Aí, eu vim pra cá, na época. Aí aqui eles tiraram esse remédio e... e eu fiquei com talidomida. Aí até hoje, eu fiquei. Até hoje eu tô tomando talidomida...Aí agora, ano passado, fez outro exame e disse que não matou a doença ainda e eu tô... voltei a tomar o mesmo medicamento que eu tava tomando pra matar a doença da hanseníase. Aí voltei agora a tomar um ano ele. Já tô terminando de encerrar pra tomar ele. Mas só que o tratamento, a doutora diz que não tem previsão de suspender o remédio, não. Assim!” (Raquel)

Para o MS a alta por cura significa retirar do registro ativo os doentes logo que tomem as doses previstas da PQT, independente se ficaram ou não incapacidades e sequelas. Assim, o MS é enfático ao afirmar que a cura da hanseníase consiste na morte do bacilo de Hansen. Neste sentido, pode-se questionar o significado de cura para estes pacientes, pois convivem com a possibilidade de volta dos sintomas da hanseníase, mesmo após a cura. Refletir sobre a cura remete pensar no discurso conflitante dos entrevistados, por meio da qual a ideia de cura remete ao estado anterior ao diagnóstico da doença. Apesar da incompreensão de que a cura não significa voltar ao corpo de antes, isto é, se após a cura a pessoa já tiver incapacidades e sequelas instaladas, elas continuarão, e mais, se o autocuidado não for incorporado no cotidiano, além das sequelas já instaladas é possível o aparecimento de novas deformidades (BATISTA, 2014).

\footnotetext{
"Nossa! No dia em que eu tomo esse remédio, nossa! Dá um mal estar, assim, no estômago, assim. Porque é muito remédio de uma vez, né." (Jesabel)

"Se deixar de tomar é complicado, porque aí vem tudo de novo. É um tratamento que não acaba, né, é pro resto da vida." (Misael)
}

\section{Estigma e Preconceito}

Em se tratando de hanseníase, estigma e preconceito andam lado a lado. Estigma conforme o conceito de Goffman, já tratado anteriormente.

Enfrentar a hanseníase, que é uma doença carregada de estigma desde os primórdios da humanidade, não é fácil pois os sintomas, as dores e as deformidades físicas afetam a vida pessoal e de relação do paciente. Porém, se a doença vier acompanhada de preconceito e discriminação por parte daqueles que convivem com o doente, diariamente, mais difícil será a cura e a reabilitação destes pacientes (EIDT, 2000). Questionada sobre qual sua maior dificuldade no dia a dia, Salma não hesita:

“É os preconceito!” (Salma) 
Apenas quatro pacientes $(14,81 \%)$ não falaram sobre preconceito e oito $(29,63 \%)$ relataram não ter sofrido nenhum tipo de preconceito, porém, suas falas não são conclusivas:

"Vou falar... Vou... Meio que... Pra mim, eu acho que não. Eu não falo muito, entendeu? Eu...

Pra mim, eu faço de conta que nem... que tem." (Esdras)

Já os demais, 55,56\% (15) relataram ter sofrido preconceito, destas, duas contaram que têm preconceito consigo mesmos e muitos evitam falar que têm a doença com medo de sofrerem preconceito.

\footnotetext{
“Em outros lugares tem. Essa pessoa fala: 'Não! Você tá com hanseníase.' A pessoa já te fica, né... te olhando, assim...meio... meio, assim, atravessado. Meio, assim... Na própria família mesmo... As pessoas falam assim: 'Nossa! Não precisa separar as suas roupas? Separar o seu prato? A sua colher?' E eu digo: 'Gente! Pelo amor de Deus, né.’” (Lídia)
}

Segundo Simões e Dallelo (2005), normalmente o diagnóstico de hanseníase choca o paciente que, mesmo sabendo que se trata de uma doença curável e não transmissível, internaliza a necessidade de camuflar a verdade para os outros e passa a sentir o peso do estigma. A mudança de comportamento está intimamente ligada ao estigma, termo esse utilizado segundo o conceito de Goffman, que encontra nele três características fundamentais: as abominações do corpo, os defeitos de caráter e a procedência social. No contexto da hanseníase, o estigma refere-se ao descrédito, à desqualificação e à marginalização social em consequência das deformidades físicas do paciente. Uma vez estereotipado com tal rótulo social, o paciente de hanseníase pode instintivamente assumir duas posições: a adequação ao papel marginal a ele designado ou a tentativa de encobrir as marcas que caracterizam o estereótipo estigmatizante, com o apoio da família e dos serviços de saúde.

\footnotetext{
"Pelo menos minha família nunca notei nada, a respeito a minha pessoa, não. Mas...é como diz a...eu acho que a região, a pessoa mesmo da região, deve ter. Principalmente lá na minha região, né...interior. e aquela história de... lepra...a história da lepra, né...ai, se falar o nome...hanseníase até que...eles não tem aquele conhecimento, mas se falar na lepra, a coisa... já vê a diferença, já tem mudança...nas pessoas..." (Uriel)
}

O preconceito atinge a esfera pessoal e também profissional, pois o paciente observa as mudanças de atitude de pessoas da sua convivência e de seu ambiente de trabalho. A discriminação e o preconceito existem em nível de relacionamento interpessoal e também em nível profissional (EIDT,2000).

\footnotetext{
“Assim, no começo eu via falar, né... mas não sabia do como... do que se tratava, né. Porque, antigamente, é uma coisa que a maioria do pessoal tem preconceito. É tanto que no meu serviço
} 
poucas pessoas sabem que eu... que eu tenho, né. Porque os que souberam logo se afastaram.

Porque o preconceito, a maioria, já vem de ca... de dentro de casa.” (Lael)

O passado histórico ainda exerce influência apesar da mudança do nome, pacientes enfrentam preconceitos no meio social, pela associação com o termo lepra. A dificuldade no entendimento dos conceitos pode ser uma das causas do estigma (FEMINA ET AL., 2007).

"Essa irmã que eu tenho aí mesmo, ela me discriminou! Por... Deu hansenía nela, disse que a culpa é minha! Nossa! Eu fiquei sem chão! Depois deu no irmão também. Eu falei: ‘Gente do céu! Eu...eu transmiti a doença pros outros! 'E aí, eu fiquei louca! Deus me livre! Porque tem gente com preconceito demais! Essa que tá lá fora ela é... ela é preconceituosa demais! Oh! Irmã custosa![chora] Você desculpa, tá!" (Lia)

Muitos são os sentimentos vivenciados pelos pacientes, mas com certeza, as modificações corporais, surgidas com a doença e a necessidade de explicações contínuas sobre elas, levam o doente com hanseníase a ocultar seu corpo e sua doença. Os pacientes manifestaram desconforto pela alteração da aparência, decorrente dos efeitos das medicações e da própria evolução da doença. Muitas vezes, a aparência provoca atitudes de especulação, curiosidade e preconceito entre as pessoas do convívio do paciente (EIDT, 2000).

Conforme já discutido anteriormente, a PQT escurece a pele, e, para Nations et al ( 2009), a hanseníase é percebida como uma erupção cutânea racista. Apesar de a bula minimizar a pigmentação da pele, adverte que o efeito pode persistir por meses e até por anos após o término da terapia. Até mesmo a OMS declara que a pigmentação da pele não é um sério problema, exceto por ser esteticamente inaceitável para alguns pacientes. Nas entrevistadas realizadas pelos autores, os pacientes contestam esses argumentos, relatando que o escurecimento da pele contribui para o preconceito. Assim como relata Lídia no nosso estudo:

\footnotetext{
"É uns remédio forte! Tomava de manhã, antes do... é... depois que eu tomava café, eu tomava, né... e à noite tinha que tomar, porque tem um que toma que você não pode sair no sol porque a pele fica escura, né... e foi escurecendo... Desde o primeiro mês, você toma e não sente nada. Mas, depois, né... a minha pele foi ficando escura e ela nunca voltou... [risos] o normal ainda, né. Mas aí, é um remédio muito forte. No começo, eu passava mal mesmo. Tomava e corria pra cama e deitava porque o mundo ficava, assim... parece que tava rodando tudo, entendeu? Mas aí, depois, o organismo já foi acostumando, e depois já tomava e já não sentia tanto mal. (Lídia)
}

A experiência com a doença e suas estratégias pode levar alguns pacientes a escolherem não mais participar de determinadas atividades sociais, preferindo excluir-se por não suportar discorrer sobre a doença ou serem olhadas, pois se sentem 
envergonhadas pela sua condição. Podem também se sentir isoladas pelas outras pessoas de seus grupos (MONTAGNER, 2011).

"Eu acho que sim. Pode ser que sim, pode ser que não, mas tem um... tem umas pessoas, assim, que tem. Quem vê a pessoa enfolada, assim, igual eu tô aqui cheio de caroço e vê, tem muita gente que não...Que não entende, né. Isso é verdade. ” (Rebeca)

Atitudes de amigos, de familiares e da comunidade na qual o paciente vive, também podem fazer com que ele acabe isolando-se do convívio social. Vários são os motivos para esta auto-segregação, vivenciada pelos enfermos, pois nela recaem séculos de preconceitos e de medos, fundamentados na ignorância e na incompreensão, contribuindo para a sua auto rejeição e auto-segregação. A auto-segregação, vivenciada pelos hansenianos, altera sua vida de relação, pois eles se privam de amizades e outros relacionamentos, tão importantes para as pessoas (EIDT, 2000).

“Também tenho pressão alta, tenho diabetes. Eu moro é sozinha mesmo. Tem os vizinhos, né. Tem sobrinho, tem o tio, tem o primo, mas é mesmo que não ter. [Risos] Prefiro os estranhos do que os parentes." (Safira)

A discriminação e a rejeição ocorrem por parte daqueles que desconhecem o que é a hanseníase e deixam profundas marcas nos sentimentos dos pacientes (EIDT, 2000).

“Assim: tem um lá mesmo que eu namorava com a moça e ia casar, e aí, ele me falou, assim, que... que eu tinha...é...é...que... que ela não namorasse e nem casasse comigo, não, porque... porque eu já tenho hanseníase e que isso não sara, não. Entendeu? [risos] Falou pra ela bem assim! Ela que... não. Ela... Ela já sabia, sabe?! Mas... Ela... Porque ela já sabia, se não... Ela ficou meio assustada, mas queria acabar. [risos] É uma pessoa que não tem nada a ver, né. Assim... porque não entende, né. Porque igual os médicos já falaram, assim, que tando tomando... depois que toma os remédios, não tem perigo nenhum mais, né. Pois é. É. Porque eles não entendem, né. Porque eles não entendem. Porque falam... [risos]” (Isaque)

A construção sócia histórica da hanseníase contribuiu para a solidificação do estigma e preconceito, caracterizados pelo medo do contágio e pela ignorância tanto dos familiares e dos próprios doentes quanto da sociedade em geral, facilitando a propagação da doença e a instalação ou agravamento das incapacidades e deformidades físicas. Essa situação pode ser atribuída tanto à baixa escolaridade da maioria dos entrevistados como pela possível ineficácia das ações educativas em hanseníase (BATISTA, 2014).

Bury (2011) constatou que o indivíduo é inevitavelmente levado a rearranjar seus envolvimentos pessoais e comunitários mais amplos. A ruptura da amizade e do envolvimento com a comunidade é causada não apenas por limitações funcionais, mas também pelo constrangimento que tais incapacidades criam. Um simples passeio torna- 
se uma ocasião que precisa ser planejada ao extremo. Assim, as deficiências do isolamento social e da dependência que fluem a partir dessas rupturas no intercurso social não se originam simplesmente da habilidade ou inabilidade de realizar tarefas e atividades. Os indivíduos começam a restringir seu território a locais familiares onde há pouca probabilidade de serem expostos aos olhares e às perguntas de conhecidos e estranhos.

O preconceito vivenciado pelos entrevistados manifesta-se pela perda de amigos, perda do emprego e convívio social. Os entrevistados percebem a mudança de atitude de amigos e conhecidos que, anteriormente, frequentavam a casa do doente e após saberem sobre a hanseníase nunca mais aparecem. É necessário interesse em lutar contra o estigma imposto ao paciente, assim como também é preciso compreender que as lesões físicas da hanseníase podem ser graves e os prejuízos sociais e morais causados são ainda maiores (EIDT, 2000).

\footnotetext{
"Aí eu lembro que eu não tinha nada pra tomar café em casa, aí eu vou lá na minha irmã. Aí eu lembro que...e ela nem sabia que eu tinha essa doença...porque eu nunca falei nada assim. [...] Eu fui pegar o pão lá, por que eu acho que a minha mão encostou na outra, assim... 'ai, minha irmã' aí ela não me deu mais pão. Aí eu pensei 'ixi, se ela soubesse que eu tenho eu não ia nem pisar'. 'Não, maninha, desculpa. Eu não vi o outro pão'. Aí eu fiquei pensando, depois eu fiquei pensando...eu ia contar pra minha família, mas...melhor não. Acho que eles não vão deixa eu compartilhar na casa deles, comer, essas coisa. Aí eles vão lá na minha casa também, a gente faz um almoço de família, enfim. Aí se eles souber, eu vou perder esse contato, cê entendeu? Esse que é meu medo... Até meus vizinho... às vez eu tô lá fora assim... "pois é, cê nunca melhora, né"... eu 'pois é, nunca melhoro, esse reumatismo tá me matando'. Porque eu tenho medo de falar: ah, é hanseníase. E as pessoa se afastar de mim... e tá tão bom do jeito que tá, sem ninguém sabe de nada [risos]" (Betsabé)
}

\section{Dificuldades após o diagnóstico de hanseníase}

De acordo com Eidt (2002), a hanseníase deve ser considerada sob dois aspectos: como uma doença contagiosa e como uma doença capaz de provocar deformidades físicas e incapacitantes. Apesar da diminuição da prevalência da hanseníase, após a introdução da PQT, a situação referente às deformidades e às incapacidades físicas continuam inalteradas. Para um paciente com sequelas, a cura completa de sua moléstia só poderá ocorrer após a sua correção cirúrgica e respectivo suporte emocional.

\footnotetext{
"Sinto reações, eu sinto dores. Muitas dores. (...) Na verdade, eu não tenho muita força... é...assim, eu sou uma pessoa...intocada. É... eu sinto dores, a pessoa bater dói muito, então eu vou...acho que... até pelo fato de eu sentir essas dor eu não... deixo tocar muito, tenho medo de
} 
machucar. E pancada, se eu bater em algum outro lugar, dói muito, muito, muito. É uma dor insuportável. Então eu...não consigo fazer coisas assim não. Agachar também, não tenho muita força, tenho que me apoiar um pouco e eu não tenho força nas mãos. Eu não corto um frango [risos]. (Salomé)"

Ao término do tratamento, as pessoas esperam que as alterações corporais desapareçam ou, no mínimo, diminuam, porém, no caso da hanseníase, nem sempre os sinais e sintomas somem após a alta por cura, e tampouco há a suspensão de medicamentos, pois a interrupção da PQT não implica na suspensão de outros medicamentos e tratamentos. O paciente pode receber alta por cura e continuar o tratamento para reação hansênica por longos períodos (BATISTA, 2014).

\begin{abstract}
“Ah! Tá indo, né. Que... que... O negócio aqui da cara, né. Aí diz que vão tratar, né. Vai ver. Eu tô esperando pra ver se... Olha! Tem dia que na cabeça tá... o couro da cabeça tá tão diluído que eu não posso nem pentear o cabelo. Aqui tudo dói, na testa aqui... Esse negócio aqui faz tempo que eu tenho medo, sabe. Isso aqui foi uma impinja. Esse negócio bem aqui, sabe [mancha na bochecha]. Ela começou aqui, e aí, em ensinaram, então, a passar aquele azeite de castanha, sabe. Aí, eu passei, e aí, cresceu, tomou minha cara quase toda, ficou toda manchada, né. Isso aqui era bem apagadinha. Com um ano, por causa da doença, quando incha, fica assim. O pé dói só em junta. Agora, as junta, tem dia que quando eu vou levantar pra ir no banheiro, me segurando na parede, porque é mesmo... é mesmo que tá botando um dedo dentro de uma moita de espinho." (Safira)
\end{abstract}

Participantes do estudo de Nunes et al. (2011), relataram que após o diagnóstico de hanseníase, sua vida mudou drasticamente. Por ser uma doença incapacitante, alguns portadores de hanseníase manifestaram que a doença lhes causa dores por todo o corpo, pondo em risco a harmonia de sua vida, impedindo-os de trabalhar e realizar tarefas diárias, impondo limitações às suas atividades, acarretando verdadeiras mudanças em suas vidas, como também a diminuição das atividades de lazer e sociais. Um dos entrevistados manifestou diminuição das atividades sociais, não apenas em decorrência das dores físicas, mas também por opção própria, o que pode levar a um isolamento social. Outro achado foi o relato de ocultação da doença por um sujeito do estudo, mesmo ao ser indagado sobre mudanças na sua aparência física, em consequência do tratamento medicamentoso. Estes achados podem ser atribuídos ao estigma e preconceito em relação à hanseníase, que existem desde tempos remotos, quando a doença ainda era denominada de lepra.

"Doía demais os pés, assim! Os nervos... Esses nervos, assim, tudo doía que era dor que eu faltava não aguentar! Ainda não posso [trabalhar] ainda por causa do sol. Quando eu são... eu saio, eu sinto, assim, arder. Entendeu? Assim...nos... nos nervo. Assim, no rosto, eu sinto, assim, querendo queimar quando eu tô no..." (Isaque)

A hanseníase, por ser uma doença com alto poder incapacitante, interfere 
drasticamente na vida social do paciente, acarretando perdas econômicas e traumas psíquicos. O fato de não poder mais fazer o que se fazia antes, limitado pela doença, faz com que o indivíduo se sinta inferiorizado, desmotivado e desqualificado diante da sociedade. As incapacidades e deformidades físicas, a indisposição e a preocupação gerada pela doença, bem como o tratamento, que muitas vezes ocasiona reações hansênicas, limitam a capacidade produtiva dos indivíduos fazendo com que eles sejam afastados do trabalho (BATISTA, 2014).

Qualquer programa de controle da hanseníase que não busque a cura do doente no seu todo, buscando também a recuperação de seus sentimentos, estará apenas matando o bacilo de Hansen e não curando completamente a hanseníase (EIDT, 2000).

"Porque atingiu também os nervo dos meus pés. Eles pegam meu coisa, eu terminei o tratamento, não deu mais nada, realmente como ele falou, e eu espero que não dê mesmo, porque...eu peço a deus de não tomar mais remédio, de tanto..eu tenho tomado muito remédio. E esses remédio acaba com a gente..mas, a gente nunca mais fica bom, filha. Nunca mais, nunca mais. Eu era uma pessoa, essa daí[filha] sabe a minha vida lá em casa, eu não parava, ainda tava de noite eu trabalhava, na minha roça eu inventava uma coisa, mim pegar meu dinheiro, né... e hoje eu me acho assim...sem poder fazer nada...e eu não gosto de tá pedindo nada a ninguém..." (Ália)

No questionário não havia a pergunta acerca de doenças concomitantes, mesmo assim é interessante comentar os achados. Alguns entrevistados informaram ao longo da entrevista, relatando que essa enfermidade causa alguma dificuldade no dia a dia ou é ocasionada pela medicação: doença de Chagas, lúpus, endometriose, alergia na pele, esquistossomose, esquecimento, problema de visão, problema vascular, diabetes e hipertensão, enfisema pulmonar.

\section{Deixou de fazer/algo mudou após o diagnóstico}

Outra pergunta feita na entrevista, era se o paciente deixou de fazer alguma atividade, ou se havia percebido alguma mudança no dia a dia.

\footnotetext{
"Muitas coisas eu deixei de fazer, muitas mesmo. Praticar atividades físicas mesmo, eu fazia muito, 3 a 4 vezes ao dia, eu não faço mais[...]. Porque eu sei que se eu correr 15 minutos, passo duas semanas que eu não consigo pegar a minha filha no colo. Assim, é dores nas pernas, nos braço. Não posso forçar mesmo. Forçar é...inclusive eu forcei um dia e fiquei internado oito dias. E assim, forcei sem perceber, em casa mesmo, trabalhando em casa. ” (Elias)
}

Ainda que o diagnóstico precoce e o adequado tratamento tenham reduzido o 
número de pacientes com sequelas da hanseníase, o potencial incapacitante é fato concreto e pode-se esperar um número importante de pacientes curados com chances de desenvolver deformidades físicas mesmo após a alta por cura (EIDT, 2000). "Mudou na... das dor - que eu venho sentindo direto nas... na... nas junta. Tem dia que, pra
trabalhar, é um sacrifício. Trabalho porque eu preciso, né! Não posso ficar em casa!" (Joabe)

Realizar as atividades domésticas e profissionais requer mudanças e readaptações na vida destes pacientes, pois, ao contrário das enfermidades não crônicas, as alterações na vida cotidiana são passageiras, enquanto as enfermidades de longa duração implicam novos rearranjos da vida e a busca da normalidade (MONTAGNER, 2011).

"Muitas coisas que eu fazia e eu não faço mais por causa dessa mão. Eu tinha que fazer a cirurgia dentro do nervo. Aí, se eu for fazer, aí atinge e dói. Aí, eu não... Deixei. Ela trouxe um tipo de esquecimento que eu tenho também. Não sei se foi ela. Deu esse esquecimento também em mim, na minha cabeça, assim, que... Parei de andar sozinha por causa disso. Às vezes, eu tô numa parada esperando um ônibus e o ônibus passa e eu tô vendo e me passou um branco. E depois que passa, eu falei: 'ué! Aquele ônibus era o meu! Ah! Vem outro.' E aí? Que situação, né! [...]" (Jesabel)

No estudo de Bury (2011), um trabalhador manual e um empresário sofreram o início de uma doença sistêmica grave. No curto prazo, o empresário teve problemas mais sérios pois não podia contar com a ajuda do Estado como o trabalhador manual. Porém este enfrentou dificuldades maiores no longo prazo devido às definições administrativas de deficiência. Além do que, a dor e o desconforto juntam-se a essas preocupações e produzem tristeza e depressão.

"Eu tenho problema, a dormência, ela vem até aqui ó, nesse pé. E eu tenho um problema muito sério. Tá vendo essas mancha aqui, ainda bem que o machucado em mim sara rapidinho. Tem vez eu vou pro fundo do quintal, fazer limpeza, cortar galho, essas coisa. Aí cai uma galha aqui, arrebenta minha perna eu não vejo nada. Esse aqui então [mostra um machucado cicatrizado]...eu machuquei aqui tem 15 dia que eu machuquei. Eu não sei aonde eu machuquei, não foi lá em casa, foi aqui e eu machuquei...quando eu percebi, no outro dia eu amanheci com o pé cheio de sangue, eu não sei aonde. Esse aqui também ó, arranquei um pedaço daqui ó, tá vendo? Arranquei esse pedação também não sei aonde. Eu não sinto. Então eu preciso ter esses cuidado. Mas a minha força pra trabalhar também diminuiu bastante, dos dois ano pra cá. Eu tando tomando a prednisona, até que me dá...eu fico mais forte, mas se eu deixar de tomar ele, menina, me dá uma morrença no meu corpo, que eu vou pra cama...Nossa, pra você ver. E aí eu já dei entrada duas vez no INSS, não passei, porque precisa de comprovar, a doutora falou que o que eu sinto não tem como fazer exame pra comprovar. " (Ester)

Algumas vezes, as sequelas físicas causadas pela hanseníase não são visíveis porque o doente não tem deformidade física, mas falta-lhe força nas mãos e pés, impedindo-o de realizar seu trabalho e atividades diárias. A convivência com as sequelas exige várias adaptações pessoais, tanto físicas quanto emocionais, à nova 
condição física. O ideal seria poder preveni-las, mas nem sempre isto é possível, pois a hanseníase pode seguir seu curso incapacitante, apesar da correta terapêutica instituída (EIDT, 2000).

“Porque agora, a sequela agora só tá nos meus nervo. Só tá nas mão. Tá perfeita desse jeito, mas sin... sinto dor nas mão todinha. Pego um pano de prato, cai. Vou lavar louça, quebra as louça. E na sola dos pés também. Ficou a sequela e ainda tá... Nós agora tá tratando das sequela ...Mas eu acho que essa doença também, a gente vai levando, levando, levando, levando, sara. No dia que a gente morrer, sara." (Salma)

Sousa et al (2013), corroboram com autores que afirmam que o conhecimento dos portadores sobre a hanseníase pouco está relacionado com as informações recebidas pelos profissionais da saúde e sim por própria experiência. Associado a isso, a maioria dos pacientes de seu estudo desconheciam a forma clínica da hanseníase adquirida, justificavam não lembrar devido à linguagem utilizada pelos profissionais e pela nomenclatura complicada da forma clínica. 


\section{CONSIDERAÇÕES FINAIS}

A proposta deste estudo foi observar como uma doença negligenciada, crônica e estigmatizante interfere e modifica a vida de pessoas com hanseníase e como estas gerenciam suas vidas.

O perfil das pessoas em tratamento de hanseníase, atendidos no HUB, é de residentes no DF, do sexo feminino; renda familiar de 1 a 2 salários mínimos; a composição familiar é de 3 a 4 pessoas por residência; tem ensino fundamental incompleto; são pardos; têm profissões sem carteira assinada, de baixo salário; idade entre 30 e 40 anos e a ocupação predominante é pedreiro e do lar.

A maior parte das pessoas relatou ter sequelas ou alguma dificuldade ocasionada pela hanseníase. Dos 27 entrevistados, 22 estavam em acompanhamento no HUB. A maioria teve como sintoma inicial mancha na pele.

A maioria dos entrevistados é proveniente de áreas periféricas de Brasília, entorno do DF, cidades pequenas ou áreas rurais, ou seja, lugares de mais baixa renda, menor escolaridade e com profissões menos rentáveis. Corroborando mais uma vez que a hanseníase é uma doença da pobreza.

O fato de a maioria dos entrevistados ser do sexo feminino pode estar relacionado a uma maior preocupação das mulheres com o corpo e com a estética e pela maior procura destas pelos serviços de saúde ou, também, por ser uma amostra de conveniência, pode haver este viés no estudo.

Quando o indivíduo não apresentava os sinais e sintomas clássicos da hanseníase, o diagnóstico torna-se mais difícil de ser realizado. Porém foram encontrados indivíduos com manchas e mesmo assim houve demora no diagnóstico. Estes dados demandam certa atenção, pois se caso a hanseníase não for devidamente diagnosticada e tratada, ou, ainda, diagnosticada tardiamente, poderá repercutir em graves alterações físicas, emocionais e sociais.

Observou-se que, por ser uma doença antiga, citada na bíblia, continua envolta em preconceitos, estigmas e desconhecimentos acerca de suas características, transmissibilidade e tratamento. Apesar de ter cura, o preconceito em torno da doença persiste, principalmente, devido à falta de informações e conhecimento. 
Além do preconceito em relação à doença em si, muitas pessoas relataram que o remédio escurece a pele, sendo este um problema relevante, pois afeta a autoestima. Visto isso, em relação à medicação, deveria haver mais estudos sobre novas drogas, mais atuais e eficazes para o tratamento da hanseníase.

Pesquisas que abordam dificuldades diárias e sua adaptação à vida diária dos pacientes são escassas. Geralmente os programas de controle de hanseníase incluem diagnóstico, tratamento e acompanhamento. As campanhas enfatizam a cura, porém, deveria haver uma ênfase no acompanhamento dos pacientes com sequelas e reações, pois apesar de a doença já ter sido curada pelo tratamento, observei que a grande maioria dos pacientes se queixa de alguma sequela, e, por menor que seja, acaba prejudicando alguma atividade da vida diária.

O habitus precário fica evidente na pesquisa quando se observa os dados de renda familiar, escolaridade e quantidade de pessoas que moram na mesma residência de acordo com outros estudos encontrados na literatura.

A hanseníase é uma doença promotora e perpetuadora da pobreza, é um sintoma de desvantagem social, intelectual, de desenvolvimento, e, claro, de pobreza. A população acometida compartilha características que lhes permite persistir em condições de pobreza, sugerindo um habitus em comum.

O estudo sugere também que, após o diagnóstico de hanseníase, ocorrem diversas mudanças e adaptações à nova realidade destes pacientes, tanto na vida social, familiar e profissional, constituindo o que Michael Bury conceitua como ruptura biográfica. Pode-se inferir que as pessoas com hanseníase também passem por momentos de descontinuidade ou de ruptura no curso de suas vidas.

As sequelas físicas foram motivo de afastamento ou diminuição da capacidade de trabalho. Para os entrevistados, o trabalho é associado à utilidade, reconhecimento e valorização social. A partir do momento em que não podem mais trabalhar ou têm sua capacidade laboral diminuída, os entrevistados demonstraram sentir-se desvalorizados, incapazes e muitas vezes menosprezados. As mulheres do lar demonstraram maior sensibilidade nesses aspectos, provavelmente por ser este um trabalho atribuído a elas e sendo frustrante quando não conseguem realizar suas tarefas domésticas rotineiras. 
As incapacidades físicas ocasionadas pela hanseníase ou pelas reações hansênicas, como a perda de sensibilidade cutânea e a perda da força muscular foram relatadas como dificuldades na execução de tarefas cotidianas, exigindo adaptações físicas e emocionais.

O presente estudo apresenta limitações por se tratar de entrevistas realizadas no próprio local da consulta, nenhum dos entrevistados queixou-se do atendimento recebido. A técnica da entrevista por si só é limitada, há todos os fatores que interferem nas respostas: foi realizada no próprio hospital, ser gravada, timidez, constrangimento em falar da própria condição ou da doença em si. Alguns entrevistados forneceram mais detalhes, contando toda a sua história de vida, enquanto alguns responderam somente o que foi perguntado, sem entrar em maiores detalhes. Quando percebido este perfil, a entrevistadora, percebendo o limite do indivíduo, respeitou-o.

Por fim, constatou-se que o tratamento em si e todas as questões a ele associadas, como os efeitos da medicação, deslocamentos periódicos para consultas, recidivas, tratamento longo e contínuo, faltas no trabalho, isolamento social, podem ser fortes indicadores de inúmeras dificuldades e questões nem de longe sonhadas ou levadas em consideração quando se elaboram protocolos de atendimento ou políticas voltadas para um grupo social complexo e em vulnerabilidade. 


\section{REFERENCIAS}

ARANTES, C.K. et al. Avaliação dos serviços de saúde em relação ao diagnóstico precoce da hanseníase. Epidemiol. Serv. Saúde, Brasília, v. 19, n. 2, p. 155-164, abr-jun, 2010.

ARAÚJO, F.M. de B., ALVES, E.M. \& CRUZ, M.P. Algumas reflexões em torno do conceito de campo e de habitus na obra de Pierre Bourdieu. Revista Perspectivas da Ciência e Tecnologia, v.1, n.1, jan-jun 2009.

ARAUJO, Marcelo Grossi. Hanseníase no Brasil. Revista da Sociedade Brasileira de Medicina Tropical. v. 36, n. 3, pág. 373-382, mai-jun, 2003.

ARROW, K. Uncertainty and the welfare economics of medical care. American Economic Review 53(5):89-121,1963.

BARATA, Rita Barradas. In: Tratado de Saúde Coletiva. CAMPOS, Gastão Wagner de Sousa et al. Ed. Hucitec, São Paulo, 2012.

BARATA, R.B., BRICEÑO-LEÓN, R.E., (Orgs). Doenças endêmicas: abordagens sociais, culturais e comportamentais. 376 p. ISBN: 85-85676-81-7. Rio de Janeiro: Editora FIOCRUZ, 2000.

BARDIN, Laurence. Análise de Conteúdo. São Paulo: Edições 70, 2011.

BATISTA, Talitha Vieira Gonçalves. Representações Sociais do Corpo para Pessoas Acometidas pela Hanseníase: Processos Saúde/Doença. Dissertação apresentada como requisito para obtenção do Título de Mestre pelo Programa de Pós-graduação em Desenvolvimento Humano: Formação, Políticas e Práticas Sociais da Universidade de Taubaté, 2014.

BOLTANSKI, Luc. As classes sociais e o corpo. Rio de Janeiro: Edições Graal, 1979.

BOURDIEU, Pierre. Esboço de uma teoria da prática. In: ORTIZ, R. (org.), Pierre Bourdieu. São Paulo: Ática, 1983. Meditações Pascalianas. Rio de Janeiro: Bertrand Brasil, 2001. Questões de Sociologia. Lisboa: Fim de Século, 2003. . O Poder Simbólico. Rio de Janeiro: Bertrand Brasil, 2004. A Distinção: crítica social do julgamento. São Paulo: Edusp; Porto

Alegre: Zouk, 2007. 
BRASIL. Constituição da República Federativa do Brasil de 5 de outubro de 1988. Disponível em <http://www.planalto.gov.br/ccivil_03/constituicao/constituicao.htm>. Acesso em: 27 abr. 2014.

BRASIL. Ministério da Saúde. Guia de Vigilância Epidemiológica. Brasília: Ministério da Saúde, 2014a.

BRASIL. Ministério da Saúde. Portal da Saúde. Registro ativo: número e percentual, casos novos de hanseníase: número, coeficiente de percentual, faixa etária, classificação operacional, sexo, grau de incapacidade, contatos examinados, por estados e regiões, Brasil, $2014 . \quad$ Disponível em <http://portalsaude.saude.gov.br/images/pdf/2015/julho/27/Dados-2014---final.pdf>. Acesso em: 14 de junho de 2016.

BRASIL. Ministério da Saúde. Portal da Saúde. Indicadores Epidemiológicos e Operacionais de Hanseníase. http://portalsaude.saude.gov.br/images/pdf/2015/outubro/29/S--rie-Hist--rica-Hansen-ase-2000---2014.pdf>. Acesso em: 14 de junho de 2016.

BRASIL. Secretaria de Vigilância em Saúde. Departamento de Análise de Situação em Saúde. Saúde Brasil 2013: uma análise da situação de saúde e das doenças transmissíveis relacionadas à pobreza / Ministério da Saúde, Secretaria de Vigilância em Saúde, Departamento de Análise de Situação em Saúde. Brasília: 2014b.

BRASIL. Secretaria de Vigilância em Saúde. Departamento de Vigilância de Doenças e Agravos não Transmissíveis e Promoção da Saúde. Saúde Brasil 2014: uma análise da situação de saúde e das causas externas / Ministério da Saúde, Secretaria de Vigilância em Saúde, Departamento de Vigilância de Doenças e Agravos não Transmissíveis e Promoção da Saúde. Brasília, 2015.

BRASIL. Ministério da Saúde. Secretaria de Atenção à Saúde, Departamento de Atenção Básica. 2a ed. rev. Brasília: Ministério da Saúde, 2008.

BRASIL. Ministério da Saúde. Secretaria de Políticas de Saúde. Departamento de Atenção Básica. Guia para o Controle da Hanseníase. (Série A. Normas e Manuais Técnicos; n. 111) Brasília: Ministério da Saúde, 2002. 
BURY, Michael. Doença crônica como ruptura biográfica. Revista Tempus Actas de Saúde Coletiva, v. 5, n.2, Brasília, 2011.

CANGUILHEM, Georges. O normal e o patológico. Forense Universitária, 6.ed. rev. Rio de Janeiro, 2009.

CAPRARA, Andrea. RODRIGUES, Josiane. A relação assimétrica médico-paciente: repensando o vínculo terapêutico. Ciência \& Saúde Coletiva, 9 (1):139-146, 2004.

EIDT, Leticia Maria. O mundo da vida do ser hanseniano: sentimentos e vivências. Dissertação de Mestrado, PUC. Porto Alegre, 2000.

FEKETE, Maria Christina. Estudo da acessibilidade na avaliação dos serviços de saúde. In: SANTANA, J.P. (Org.). Desenvolvimento Gerencial de Unidades Básicas do Sistema Único de Saúde. Brasília: Opas/OMS - Representação do Brasil, 1997.

FEMINA, Luana Laís; SOLER, Ana Claudia Parra; NARDI, Susilene Maria Tonelli; PASCHOAL, Vânia Del'Arco. Lepra para hanseníase: a visão do portador sobre a mudança de terminologia. Hansenologia Internationalis, 32 (1): 37-48, 2007.

FERREIRA, Isis Polianna Silva. Estudo do perfil e da satisfação com o tratamento dos pacientes do ensaio clínico: "estudo independente para determinar efetividade do esquema uni forme de multidrogaterapia de seis doses (U-MDT) em pacientes de hanseníase (U-MDT/CT-BR) ". Dissertação (mestrado), Universidade de Brasília, Faculdade de Medicina, Núcleo de Medicina Tropical, Programa de Pós-Graduação em Medicina Tropical, Brasília, 2013.

FOGOS, A.R. et al. Análise dos motivos para o abandono do tratamento - o caso dos pacientes hansenianos da Unidade de Saúde em Carapina/ES. Hansen. Int., 25(2): 147$156,2000$.

GARCIA, Leila Posenato et al. Epidemiologia das doenças negligenciadas no Brasil e gastos federais com medicamentos. Brasília: Instituto de Pesquisa Aplicada, 2011.

GARCIA, Maria Manuela Alves. O campo das produções simbólicas e o campo científico em Bourdieu. Cad. Pesq., São Paulo: n.97, p. 64-72, maio 1996.

GODOY, Arilda Schmidt. Pesquisa qualitativa: tipos fundamentais. Revista de 
Administração de Empresas. São Paulo, v. 35, n. 3, p.20-29, mai/jun, 1995.

GOFFMAN, Erving. Estigma: notas sobre a manipulação da identidade deteriorada. Rio de Janeiro: LTC, 1988.

GOULART, Isabela Maria Bernades; ARBEX, Guilherme Leonel; CARNEIRO, Marcus Hubaide; RODRIGUES, Mariana Scalia; GADIA, Rafael. Efeitos adversos da poliquimioterapia em pacientes com hanseníase: um levantamento de cinco anos em um Centro de Saúde da Universidade Federal de Uberlândia. Revista da Sociedade Brasileira de Medicina Tropical 35(5): 453-460, set-out, 2002.

HOTEZ, Peter J. et al. Incorporating a Rapid-Impact Package for Neglected Tropical Diseases with Programs for HIV/AIDS, Tuberculosis, and Malaria. PLoS Med 3(5): e102, jan. 2006a. Disponível em <http://www.plosmedicine.org/article/info\%3Adoi\%2F10.1371\%2Fjournal.pmed.00301 2>. Acesso em: 27 abr. 2014.

HOTEZ, Peter et.al. The Neglected Tropical Diseases: The Ancient Afflictions of Stigma and Poverty and the Prospects for their Control and Elimination. Hot Topics in Infection and Immunity in Children. New York, 2006b.

IGNOTTI, E. et al. Estudo da adesão ao tratamento da hanseníase no município de Duque de Caxias. Rio de Janeiro. Abandonos ou abandonados? Hansen. Int. ,26(1):23$30,2001$.

LE BRETON, David. A Sociologia do Corpo. Petrópolis: Vozes, 2007.

LOPES, V.A.S.; RANGEL, E.M. Hanseníase e vulnerabilidade social: uma análise do perfil socioeconômico de usuários em tratamento irregular. Saúde debate. V. 38, n. 103. P. 817-829. Rio de Janeiro, out-dez, 2014.

MAGALHÃES, M. C. C.; ROJAS L. I. Diferenciação territorial da hanseníase no Brasil. Epidemiol. Serv. Saúde v.16 n.2. Brasília, jun. 2007.

MEDEIROS, Cristina Carta Cardoso de. Habitus e corpo social: reflexões sobre o corpo na teoria sociológica de Bourdieu. Revista Movimento: Porto Alegre, v. 17, n.01, p.281300, janeiro/março de 2011. 
MINAYO, Maria Cecília de Souza (Org.). Pesquisa Social: teoria, método e criatividade. Rio de Janeiro: Editora Vozes, 1994.

MONTAGNER, Maria Inez. Mulheres e câncer de mama: experiência e biografias cindidas. Tese de doutorado. Campinas, 2011.

MONTAGNER, Maria Inez; MONTAGNER, Miguel Ângelo. Ruptura biográfica, trajetórias e habitus: a miséria do mundo é um câncer. Revista Tempus Actas de Saúde Coletiva, v. 5, n.2, Brasília, 2011.

MONTAGNER, Miguel Ângelo. Pierre Bourdieu, o corpo e a saúde: algumas possibilidades teóricas. Ciência Saúde Coletiva. Rio de Janeiro: v.11, n.2, p.515-526, abr-jun.2006.

MONTAGNER, Miguel Ângelo. Trajetórias e biografias: notas para uma análise bourdieusiana. Sociologias, ano 9, nº 17, jan- jun, p. 240-264. Porto Alegre, 2007.

NATIONS, Marilyn K.; LIRA, Geison Vasconcelos; CATRIB, Ana Maria Fontenelle Catrib. Estigma, metáforas deformadoras e experiência moral de pacientes com hanseníase multibacilar em Sobral, Ceará, Brasil. Cad. Saúde Pública, vol.25, no.6, jun., 2009.Rio de Janeiro, 2009.

NERY, Joilda Silva et al. Effect of the Brazilian Conditional cash transfer and primary health care programs on the new case detection rate of leprosy, PLOS Neglected Tropical Diseases Journal (online), novembro, 2014.

NOGUEIRA, Maria Alice. Bourdieu \& a Educação. Belo Horizonte: Autêntica, 2004.

NOGUEIRA, Roberto Passos (Org.). Determinação Social da Saúde e Reforma Sanitária. Rio de Janeiro: Cebes, 2010.

NUNES, Joyce Mazza; OLIVEIRA Eliany Nazaré; VIEIRA, Neiva Francenely Cunha. Hanseníase: conhecimentos e mudanças na vida das pessoas acometidas. Ciência \& Saúde Coletiva, vol.16, supl.1, Rio de Janeiro, 2011.

PEREIRA, Maria das Graças Alves ET AL. A Relação Médico-Paciente em Rio Branco/AC sob a Ótica dos Pacientes. Revista da Associação Médica Brasileira, 51(3): 153-7, 2005. 
PETERS, Ruth M. H. ET AL.The Meaning of Leprosy and Everyday Experiences: An Exploration in Cirebon, Indonesia. Journal of Tropical Medicine,Volume 2013, Article ID 507034, 10 pages, 2013.

PONTES, Flávio. Doenças negligenciadas ainda matam 1 milhão por ano. Revista Inovação em pauta, Brasília: Finep, 2009.

PUBLIC LIBRARY OF SCIENCE (PLOS). PLOS Neglected Tropical Diseases Journal Scope. Disponível em <http://www.plosntds.org/static/scope>. Acesso em: 27 abr. 2014.

ORGANIZAÇÃO MUNDIAL DA SAÚDE (OMS). Estratégia Global para Aliviar a Carga da Hanseníase e Manter as Atividades de Controle da Hanseníase (Período do Plano: 2006-2010). 2005.

RAMOS JÚNIOR, Alberto Novaes et.al. Pesquisas em hanseníase: contextos e agendas. In. Universidade de Brasília-UnB. Hanseníase: avanços e desafios. NESPROM, p.455490, p. 478. Brasília, 2014.

RESENDE, Danielly Mendes; SOUZA, Marise Ramos de; SANTANA, Cristiane Ferreira. Hanseníase na Atenção Básica de Saúde: principais causas da alta prevalência de hanseníase na cidade de Anápolis-GO. Hansenol. int. (Online) vol. $34 \mathrm{n}^{\circ} 1$, Bauru, 2009.

SANTOS, Lenir. Saúde: conceito e as atribuições do Sistema Único de Saúde. Porto Alegre, 2005. Disponível em <http://www.mprs.mp.br/dirhum/doutrina/id387.htm>. Acesso em: 27 abr. 2014.

SANTOS, Pablo Silva Machado Bispo dos. A aplicabilidade dos conceitos bourdieunianos de habitus e campo em uma pesquisa na área de História da Educação. Dialogia. São Paulo, v. 6, p. 49-54, 2007.

SETTON, Maria da Graça Jacintho. A teoria do habitus em Pierre Bourdieu: uma leitura contemporânea. Revista Brasileira de Educação, n.20, maio/jun/jul/agosto de 2002.

SILVEIRA, Lara Luna da. A saúde pública na contramão da equidade: uma proposta teórico-empírica de investigação da reprodução das desigualdades sociais. Dissertação de Mestrado. Juiz de Fora, 2009. 
SIMÕES, Maria Jaciara Silva. DALLELO, Danieli. Estudo do comportamento social dos pacientes de hanseníase do município de São Carlos-SP. Revista Espaço para a Saúde, Londrina, v.7,n.1, dez 2005.

SOUSA, Adriana Alves de ET AL. Adesão ao Tratamento da Hanseníase por Pacientes Acompanhados em Unidades Básicas de Saúde de Imperatriz/MA. Sanare, Sobral, V.12, n.1, p. 06-12, jan./jun., 2013.

SOUZA, Jessé et al. A ralé brasileira: quem é e como vive. Belo Horizonte: Editora UFMG, 2009.

(Org.). A invisibilidade da desigualdade de brasileira. Belo Horizonte:

Editora UFMG, 2006.

VERONESE: Tratado de Infectologia. Editor científico Roberto Focaccia. São Paulo: Editora Atheneu, 2005. $3^{\mathrm{a}}$ edição.

WORLD HEALTH ORGANIZATION (WHO), Adherence to Long-Therm Therapies:Policy for Action,Meeting Report, Genebra, 2001. 


\section{APÊEDICES}

Termo de Consentimento Livre e Esclarecido - TCLE

Convidamos o(a) Senhor(a) a participar do projeto de pesquisa "Análise da adequação do tratamento da hanseníase em pacientes vulneráveis no Distrito Federal", sob a responsabilidade do pesquisador Cristina Hamester. O projeto visa conhecer as dificuldades enfrentadas pelos pacientes com hanseníase que são atendidos no Hospital Universitário de Brasília. Serão feitas entrevistas semiestruturadas aos pacientes para conhecer as dificuldades enfrentadas na prevenção, controle, tratamento e acompanhamento da hanseníase e, deste modo, obter depoimentos pela perspectiva do paciente. Também serão feitas entrevistas com os profissionais de saúde que atendem estes pacientes, ajudando a compreender as dificuldades encontradas no acompanhamento.

O objetivo desta pesquisa é vai analisar a adequação dos protocolos de controle, prevenção e tratamento da hanseníase, publicados pelo Ministério da Saúde e sua aplicabilidade nos pacientes atendidos no Hospital Universitário de Brasília (HUB).

$\mathrm{O}$ (a) senhor(a) receberá todos os esclarecimentos necessários antes e no decorrer da pesquisa e lhe asseguramos que seu nome não aparecerá sendo mantido o mais rigoroso sigilo pela omissão total de quaisquer informações que permitam identificálo(a). A sua participação se dará por meio de entrevista, na data combinada, com um tempo estimado de 60 minutos para sua realização.

Não há riscos decorrentes de sua participação na pesquisa, visto tratar-se de entrevista. Se você aceitar participar, estará contribuindo para conhecer as dificuldades encontradas no controle, prevenção e tratamento da hanseníase sob a perspectiva dos profissionais de saúde e dos pacientes atendidos no HUB.

$\mathrm{O}$ (a) Senhor(a) pode se recusar a responder (ou participar de qualquer procedimento) qualquer questão que lhe traga constrangimento, podendo desistir de participar da pesquisa em qualquer momento sem nenhum prejuízo para o(a) senhor(a). Sua participação é voluntária, isto é, não há pagamento por sua colaboração. 
Todas as despesas que você tiver relacionadas diretamente ao projeto de pesquisa (passagem para o local da pesquisa, alimentação no local da pesquisa ou exames para realização da pesquisa) serão cobertas pelo pesquisador responsável.

Caso haja algum dano direto ou indireto decorrente de sua participação na pesquisa, você poderá ser indenizado, obedecendo-se as disposições legais vigentes no Brasil.

Os resultados da pesquisa serão divulgados na Faculdade de Ciências da Saúde podendo ser publicados posteriormente. Os dados e materiais utilizados na pesquisa ficarão sob a guarda do pesquisador por um período de no mínimo cinco anos, após isso serão destruídos ou mantidos na instituição.

Se o(a) Senhor(a) tiver qualquer dúvida em relação à pesquisa, por favor telefone para: Cristina Hamester, no telefone 8220-4995.

Este projeto foi Aprovado pelo Comitê de Ética em Pesquisa da Faculdade de Ciências da Saúde (CEP/FS) da Universidade de Brasília. O CEP é composto por profissionais de diferentes áreas cuja função é defender os interesses dos participantes da pesquisa em sua integridade $\mathrm{e}$ dignidade $\mathrm{e}$ contribuir no desenvolvimento da pesquisa dentro de padrões éticos. As dúvidas com relação à assinatura do TCLE ou os direitos do participante da pesquisa podem ser obtidos através do telefone: (61) 3107-1947 ou do e-mail cepfs@unb.br ou cepfsunb@gmail.com, horário de atendimento de 10:00hs às 12:00hs e de 13:30hs às 15:30hs, de segunda a sexta-feira.

Este documento foi elaborado em duas vias, uma ficará com o pesquisador responsável e a outra com o Senhor(a). 
Nome / assinatura

Pesquisador Responsável

Cristina Hamester

Brasília, __ de ___ de ___ 


\section{Roteiro de entrevista com pacientes}

1 - Nome:

2 - Sexo: ( ) Feminino ( ) Masculino

3 - Endereço:

4- Data de nascimento:

5 - Escolaridade: quantos anos estudou?

6- Qual sua raça/cor?

7- Qual a sua ocupação? É registrado? No que costuma trabalhar/profissão?

8 - Quantas pessoas moram na sua casa? Tem filhos?

9 - Somando a renda de todas as pessoas que moram na sua casa, qual é a renda?

10 - Como começou a doença?

11 - Há quanto tempo recebeu o diagnóstico? Lembra em que centro de saúde foi?

12 - Faz o acompanhamento sempre no mesmo lugar ou começou em outro centro de saúde?

13- Como está sendo o tratamento/acompanhamento? Sente-se bem atendido?

14 - Quem explicou sobre a doença (médico/enfermeiro/auxiliar/ACS)? Recebeu/recebe orientações de quem? Conseguiu entender as explicações?

15 - Como foi a sua reação ao diagnóstico?

16 - Como o sr./sra. toma a medicação? Tem dúvidas/dificuldades? Quais?

17 - Há algum familiar com a doença também?

18 - Algo mudou (no trabalho, amigos, família) depois que teve o diagnóstico de hanseníase?

19- Sofre ou sofreu algum tipo de preconceito por causa da doença?

20- Deixou de realizar atividades depois do diagnóstico? Quais?

21- Qual a maior dificuldade que encontra no dia a dia desde que tem hanseníase? 